\title{
Protestanti u službi Petrovaradinske pukovnije u drugoj polovici 18. stoljeća
}

Autor u radu analizira prisutnost protestanata u službi Petrovaradinske pukovnije na temelju službenih pukovnijskih serijalnih izvora i tri cjelovita popisa pukovnije iz 1767., 1772. i 1792. godine. Protestanti su promatrani iz perspektive aktivne vojne službe kao istaknuti pojedinci unutar časničkoga kadra i kao vjerska skupina i manjina među običnim krajišnicima. Prikazano je stabilno postojanje protestantskoga elementa na svim razinama pukovnijske službe kroz promatrana desetljeća 18. stoljeća, a što je predstavljalo posebnost Petrovaradinske pukovnije u odnosu na ostale pukovnije Slavonske i Hrvatske vojne krajine toga razdoblja.

Ključne riječi: Vojna krajina, Petrovaradinska pukovnija, 18. stoljeće, Srijem, protestanti, krajišnici, vojna služba

\section{Uvod}

Promatrajući reformaciju ${ }^{1}$ iz perspektive vojnokrajiškoga sustava nameće se kategorija drugoga, odnosno suparnika protiv kojega se marširalo diljem srednje Europe i koji je tijekom 18. stoljeća nadrastao i opasnost vječnoga neprijatelja s Istoka, Osmanskoga Carstva. Petrovaradinska pukovnija u tome pogledu nije bila bitno drugačija od drugih pukovnija Hrvatske ili Slavonske vojne krajine.

\footnotetext{
* Pavao Nujić, Fakultet za odgojne i obrazovne znanosti Osijek, Cara Hadrijana 10, 31000 Osijek, Republika Hrvatska, E-mail adresa: pnujic@foozos.hr

1 "Reformacija (lat. reformare, promijeniti, preobraziti) je duhovni pokret za obnovu doktrina i života crkve u Europi šesnaestoga stoljeća... Kao početak reformacije slovi javno objavljivanje Lutherovih Devedeset i pet teza 31. listopada 1517., u kojima je iznio svoje argumente protiv trgovanja oproštajnicama s pozivom na raspravu o naravi i upotrebi oproštajnica. Izraz reformacija koristi se i za povijesno razdoblje od 1517. do 1618. Taj izraz ima više značenja... četiri elementa uključena u definiciju reformacije: luteranstvo, Reformirana crkva ili "kalvinizam;" "radikalna reformacija, često nazivana "anabaptizam," te "protureformacija" ili "katolička reformacija." Stanko Jambrek, Reformacija u hrvatskim zemaljama u europskom kontekstu (Zagreb: Srednja Europa, 2013), 15-16.
} 
Iako je uspostavljena i organizirana u Srijemu, uz rijeku Savu na granici prema Osmanskome Carstvu, prva formativna desetljeća obilježila su joj upravo ratovi s protestantskom Prusijom na sjevernim bojišnicama (Rat za austrijsko nasljeđe 1740. - 1748. i Sedmogodišnji rat 1756. - 1763.).

Petrovaradinska krajiška pješačka pukovnija nastala je 1747. godine na prostoru Srijema uz rijeke Savu i Dunav i postojala je sve do raspuštanja Vojne krajine 1873. Od godine 1769. nosila je i redni pukovnijski broj 68 , a od 1798. godine bila je poznata kao Krajiška pješačka pukovnija broj $9 .{ }^{2}$ Sjedište stožera nalazilo se u Mitrovici (danas Srijemska Mitrovica), dok je cijelo područje bilo podijeljeno na dvanaest pješačkih satnija. ${ }^{3} \mathrm{~S}$ obzirom da je bila dijelom Slavonske vojne krajine, odgovarala je glavnome zapovjedniku koji se sve do 1783. nalazio u Glavnome zapovjedništvu u Osijeku, a nakon toga u Petrovaradinu. ${ }^{4} \mathrm{~S}$ obzirom na dvojnu narav pukovnijskoga sustava Petrovaradinska je pukovnija bila teritorijalno-upravna i vojno-taktička cjelina. Dok se prva stavka ocrtavala na karti i obuhvaćala ukupni određeni prostor, stanovništvo i službenike, druga je bila propisana standardiziranim normama i obavezama koje su navedeni prostor i njegovo stanovništvo morali ispuniti.

Petrovaradinska je pukovnija iz vojno-taktičke perspektive na kraju Sedmogodišnjega rata (1756. - 1763.) trebala biti cjelina od 4080 aktivnih krajišnika, podijeljenih u šesnaest pješačkih i dvije grenadirske satnije te 25 članova stožera. ${ }^{5}$

\footnotetext{
${ }^{2}$ Alphons Freiherrn von Wrede, Geschichte der K. und K. Wehrmacht V (Beč: L.W Seidel \& Sohn, 1903), 288.

3 Pukovnija i satnija bile su teritorijalno-upravne, ali i vojno-taktičke jedinice s pukovnikom odnosno satnikom na čelu. Određivanje prostora koji je obuhvaćala pukovnija ili satnija vodilo se logikom mogućnosti popunjavanja propisanih kapaciteta u aktivnome ljudstvu koje su one morale imati. Stanovništvo koje je potpalo pod određenu pukovniju odnosno satniju u svemu je odgovaralo svojemu neposrednom zapovijedajućem časniku, kako u civilnim tako i u vojnim pitanjima. Pukovnik je tako imao izuzetno velike ovlasti na prostoru svoje pukovnije, a njemu su direktno odgovarali satnici koji su mu bili podređeni. Opširnije vidi u: Željko Holjevac, Nenad Moačanin, Hrvatsko- slavonska vojna krajina i Hrvati pod vlašću Osmanskog Carstva u ranome novom vijeku (Zagreb: Leykam international, 2007), 45-47; Damir Matanović, Između reformi i tradicije (Slavonski Brod: Posavska Hrvatska, 2013), 10-17.

4 Damir Matanović, Grad na granici - Slobodni vojni komunitet Brod na Savi od sredine 18. do sredine 19. stoljeća (Slavonski Brod: Hrvatski institut za povijest - Podružnica za povijest Slavonije, Srijema i Baranje, 2008), 56.

5 Navedene brojke mijenjale su se ovisno o reformama pukovnija pa je tako Petrovaradinska pukovnija do 1760. godine imala dvanaest pješačkih i dvije grenadirske satnije unutar tri bataljuna, a zatim je taj broj proširen na ukupno šesnaest pješačkih i dvije grenadirske satnije. Jedna je pješačka satnija trebala imati 240, a grenadirska 120 aktivnih pripadnika. Reforme su nastavljene i u kasnijim desetljećima te se do kraja 18. stoljeća uglavnom išlo u smjeru njihove redukcije. Međutim, zbog objektivnih problema u nedostatku stanovništva i malenih mogućnosti novačenja Petrovaradinska pukovnija u svoju aktivnu službu tijekom prva dva desetljeća nije mogla uvrstiti više od tri tisuće pripadnika, što je predstavljao veliki deficit od čak cijeloga bataljuna. Hrvatska (dalje: HR) - Hrvatski državni arhiv, Zagreb (dalje: HDA) - fond 1450 - Zbirka mikrofilmova gradiva iz inozemnih arhiva koje se odnose na Hrvatsku, Mikrofilmovi iz Austrije, Grenz Infanterie Regiment 9 (dalje: 1450), D-1738, 1759., Monath Tabella, fol. 3; HR-HDA-1450, D-1738, 1760., Monath Tabella, fol. 17.: HR-HDA-1450, D-1738, 1763., Monath Tabella Pro Mense Octobri.
} 
Pukovnijska se služba u ovome radu stoga definira ulaskom u aktivni vojni pukovnijski sastav, bilo novačenjem, premještajem ili drugim načinom pristupanja u jednu od satnija, stožer ili pak druge pomoćne djelatnosti koje su bile pod njezinim okriljem. Muškarci koji nisu bili dijelom aktivnoga vojnog sastava pukovnije, a živjeli su na njezinom prostoru, ulazili su u kategorije prekobrojnih, poluinvalida, invalida i djece. ${ }^{6}$ Dok su aktivni pojedinci uglavnom imali vojna i ratna zaduženja i obaveze, muškarci iz drugih kategorija bili su zaduženi za gospodarstvo i ekonomiju domaćinstava. U slučaju časničkoga kadra vrijedila su posebna pravila, prvenstveno iz razloga što su obavljali i upravne poslove te često nisu trajno živjeli na prostoru pukovnije. Iz vojno-taktičke perspektive pukovnije u promatranim su izvorima žene navođene rijetko i često paušalno, ${ }^{7}$ uglavnom u obliku da popisi vojnika sadrže podatke o bračnome statusu određenoga krajišnika te je li njegova supruga prisutna na lokaciji gdje on vrši službu i stanuje ili je u slučaju premještaja krajišnik došao sam bez svoje obitelji.

Prostor Srijema bio je konfesionalno heterogen u 18. stoljeću, prvenstveno napučen pravoslavnim i katoličkim stanovništvom uz manji broj pripadnika drugih vjeroispovijesti. Brojne migracije kojima se Srijem nastojao revitalizirati održavale su njegovu vjersku strukturu fluidnom. ${ }^{8}$ Premda je prisutnost protestanata na vojnokrajiškome prostoru Srijema često zauzimala sporednu ulogu ili je bila zanemarena u monografijama ili studijama koje su se doticale tih pitanja, ${ }^{9}$ ipak

6 Prekobrojni su bili vojno sposobni muškarci u dobi između šesnaest i šezdeset godina koji nisu bili uključeni u aktivnu vojnu službu i koji su bili zaduženi za obavljanje gospodarske, poljoprivredne i druge djelatnosti potrebne za funkcioniranje jednoga krajiškog kućanstva i zadruge. Poluinvalidi su bili muškarci koji nisu bili sposobni za vojnu službu, ali su mogli djelomično obavljati gospodarske i poljoprivredne djelatnosti. Puni invalidi (ili samo invalidi) nisu bili sposobni za vojnu službu niti za bilo koji oblik gospodarske djelatnosti, a u tu su kategoriju uglavnom ulazili ranjeni ratni veterani, starci i bolesni. U kategoriju djece navođeni su svi mlađi od šesnaest godina. (nap. a.)

7 Osim u slučaju ženskih zanimanja važnih za vojno-upravnu vlast, poput primalja. Više o primaljama u Vojnoj krajini 18. stoljeća u: Dubravko Habek, "Primaljstvo i prve primalje u Bjelovaru 1756.-1856., Arhiv za higijenu rada i toksikologiju 59/3 (2008): 223-232; Vesna Ćosić, Stela Fatović Ferenčić, Blaženka Miškić, "O primaljama u Brodu na Savi u XIX. stoljeću”, Acta Medica Histria Adriatica 13 (2015), br. 2: 303-316; Robert Skenderović, "Zdravstvene reforme Marije Terezije u Slavonskom provincijalu i Generale Normativum Sanitatis iz 1770., Scrinia slavonica 5 (2005): 115-143.

8 Više o konfesionalnome sastavu i migracijama u Srijemu u 18. stoljeću u: Karl Kaser, Slobodan Seljak i vojnik I/II (Zagreb: Naprijed, 1997); Dubravka Božić Bogović, "Struktura stanovništva Srijema prema vjeroispovijesti u drugoj polovici 18. i početkom 19. stoljeća na osnovi podataka kanonskih vizitacija”, Zbornik Odsjeka za povijesne znanosti Zavoda za povijesne i društvene znanosti Hrvatske akademije znanosti i umjetnosti 27 (2009): 229-291; Sanja Lazanin, "Etničke i konfesionalne skupine u istočnoj Slavoniji i zapadnom Srijemu u 18. i početkom 19. stoljeća”, Rasprave in Gradivo 57/57 (2008): 191-211; Ivica Ćosić-Bukvin, "Doseljavanje Nijemaca u Srijem tijekom 18. stoljeća”, Godišnjak njemačke narodne zajednice (2004): 241-246; Slavsko Gavrilović / Славко Гавриловић, Jevreji u Sremu и XVIII i prvoj polovini XIX veka / Јевреји у Срему у XVIII и првој половини XIX века (Beograd: Odjeljenje istorijskih nauka - SANU, 1989), Lazar Ćelap, “Kolonizacija Nemaca u današnjoj Vojvodini 1790-1792”, Zbornik matice srpske za društvene nauke / Sборник матице српске sа друштвене науке 32/33 (1962): 115-124.

9 Alexander Buczynski iznio je kratku, ali za razvoj ovoga rada važnu napomenu o koloniji protestanata u Petrovaradinskoj pukovniji, koja je nakon Povelje o toleranciji dobila mogućnost otvaranja vlastite crkve. Karl Kaser u svojoj studiji Slobodan seljak i vojnik, ujedno i jednom od najsustavnijih prikaza 
bi trebalo posebno izdvojiti dva naslova koja su u tome pogledu napravila znatan iskorak. Prvi je rad Slavka Gavrilovića "Prilog istoriji Slovaka u Staroj Pazovi 1770-1848" iz 1973., ${ }^{10}$ u kojemu se prati razvoj protestantske zajednice Slovaka koji su iz Selenča došli u Staru Pazovu 1770. godine. Druga je recentna studija Sanje Lazanin "Naseljavanje njemačkih protestantskih obitelji u Slavonsku vojnu krajinu krajem 18. i početkom 19. stoljeća" iz 2018., ${ }^{11}$ koja u središnje promatranja uzima naseljavanja njemačkih protestanata u Novu Pazovu ${ }^{12}$ i time čini znatan iskorak u proučavanju pitanja protestanata unutar Slavonske vojne krajine s posebnim naglaskom na prostoru Petrovaradinske pukovnije. $S$ druge strane, aktivna služba ili vojni aspekt same Petrovaradinske pukovnije do sada nije ozbiljnije proučavan i stoga je izostanak studija u tome smislu i očekivan. Stoga je osnovna pretpostavka ovoga rada postojanje protestanata u službi Petrovaradinske pukovnije u 18. stoljeću, dok je shodno tome cilj bio te iste protestante detektirati, zatim ih analizirati i definirati kao pojedince i skupinu promatranu iz perspektive aktivne vojne službe. S obzirom da je središnje pitanje služba protestanata u pukovniji, prvenstveno su analizirani vojni dokumenti koji se odnose na aktivnu vojnu službu, a iz kojih se tek djelomično može pratiti i opća konfesionalna struktura pukovnijskoga prostora.

Temeljni fond za proučavanje pojedinaca u aktivnoj vojnoj službi Petrovaradinske pukovnije u drugoj polovici 18. stoljeća nalazi se u Ratnome arhivu u Beču, ${ }^{13}$ dok Državni arhiv u Zagrebu posjeduje njegove mikrofilmirane snimke. ${ }^{14} \mathrm{U}$ njemu se nalaze dokumenti koji prate aktivno stanje pukovnije kroz desetljeća iako za cijeli niz godina nema niti jednoga sačuvanog izvora. Međutim, cjeloviti popisi aktivnoga stanja Pukovnije iz 1767., 1772. i 1792. godine, a koji su ujedno i

krajiškoga prostora za Slavonsku vojnu krajinu, ne daje podatke o postojanju protestantske manjine. Od drugih autora i radova u ovome kontekstu, koji su se bavili ovim područjem, izdvojio bih prvenstveno Dubravku Božić Bogović i Ivicu Ćosića Bukvina. Ćosić Bukvin dao je pregled izvora koji svjedoče o doseljenju Nijemaca u Srijem u drugoj polovici 18. stoljeća, a gdje se u nekoliko navrata spominju i protestantske obitelji naseljene u selima na prostoru pukovnije, dok je Božić Bogović iznijela nekoliko napomena o mjestimičnome postojanju protestanata i u istočnome Srijemu, ali koji nisu bili uključeni u konačne analize o njegovoj vjerskoj strukturi. Alexander Buczynski, Gradovi Vojne krajine I (Zagreb: Hrvatski institut za povijest, 1997), 129; Kaser, Slobodan seljak i vojnik; Božić Bogović, "Struktura stanovništva Srijema"; Ćosić-Bukvin, "Doseljavanje Nijemaca u Sijem".

${ }^{10}$ Slavko Gavrilović / Славко Гавриловић, "Prilog istoriji Slovaka u Staroj Pazovi 1770-1848” /Прилог историји Словака у Старој Пазови 1770-1848/, Godišnjak Filozofskog fakulteta u Novom Sadu / Годишнјак Филовофског факултета у Новом Саду / 16 (1973), br. 1: 63-68.

${ }^{11}$ Sanja Lazanin, "Naseljavanje njemačkih protestantskih obitelji u Slavonsku vojnu krajinu krajem 18. i početkom 19. stoljeća”, Migracijske i etničke teme 34 (2018): 165-198.

${ }^{12}$ Studija je svojevrstan nastavak na spomenute radove Ćelapa (1962) i Ćosića Bukvina (2004), a u kojima su iznošeni arhivski podatci, između ostaloga o migracijama njemačkih obitelji i njihovu doseljavanju na prostor pustare u blizini Stare Pazove.

${ }^{13}$ Austrija - Österreichisches Staatarchiv, Kriegsarchiv (dalje: OeStA/KA), Personalunterlagen, Musterlisten und Standestabelle der k.u.k. Armee, Peterwardeiner Grenzinfanterieregiment Nr. 9 (aufgestellt als Slavonisches Peterwardeiner GIR 9) (dalje: Pers MLST I GIR 9).

${ }^{14}$ HR-HDA-1450, svitci: D-1553 - 1557, D-1737-1749. 
okosnica rada, te brojne pristupne i premještajne liste omogućuju detektiranje i praćenje stanja protestanata u službi kroz promatrano razdoblje. Utvrđivanje činjeničnoga stanja njihova postojanja poslužilo je kao prvi korak, a nakon kojega je uslijedilo istraživanje istaknutih pojedinaca te analiza službe, strukture činova i zaduženja, mjesta podrijetla i stanovanja kao i ostalih činjenica koje se mogu saznati iz korištenih izvora te njihovo uklapanje u vojnokrajiški mikrokozmos Petrovaradinske pukovnije.

Protestanti ${ }^{15}$ su u promatranim izvorima označavani s tri različite kategorije: nekatolici (akatolisch, accatolisch), evangelici (evangelisch, evangelische Religion ili Konfesion, augsburgisch, augsburgische Religion ili Konfesion) i reformirani (reformirte, reformirte Religion ili Konfesion). Prva se kategorija "nekatolici" odnosila na sve pojedince koji su pripadali nekoj od konfesionalnih denominacija proizašlih iz reformacije, što bi značilo da ih se zbog nemogućnosti preciznijega određivanja, poput kalvinizma ili luteranstva, sve može kategorizirati isključivo samo kao protestante. Druge su dvije kategorije davale preciznije informacije. Evangelici su bili pripadnici augsburške konfesije, odnosno luterani, dok su pod stavkom "reformirani" navođeni kalvini. ${ }^{16}$

\section{Ulazak protestanata u pukovnijsku službu}

Prvi zabilježeni pojedinac u službi Petrovaradinske pukovnije za kojega se može odrediti protestantska pripadnost bio je Johann Gottfried Riegel. S njime se susrećemo preko pristupne liste datirane 1. siječnja 1767. i sastavljene u Osijek. ${ }^{17}$ Petrovaradinska pukovnija preuzela ga je $s$ istim činom i zaduženjem od Njemačke Mercyjeve pješačke pukovnije ${ }^{18}$ - gdje je do tada četrnaest mjeseci služio na mjestu furira ${ }^{19}$ - i dodijelila ga satniji Dragojević (Kupinovskoj) sa sjedištem u Kupinovu. Rođen je u Saskoj, a kao religijska pripadnost navedena mu je evangelistička. U trenutku dolaska u Srijem imao je 22 godine i nije bio oženjen. S obzirom na evangelističku odrednicu radilo se o luteranu. Kroz iduća tri mjeseca bio je jedini protestant i nekatolik ili nepravoslavac u cijeloj Pukovniji, koja je

\footnotetext{
${ }^{15}$ Protestantizam (lat. protestari, prosvjedovati, protiviti se) ima danas dva temeljna značenja. To je u širem smislu naziv za crkve proizašle iz reformacije u šesnaestom stoljeću, dok se u užem smislu radi o nazivu za luteransku tradiciju reformacije. U ovomu se slučaju, kao i u cijelome radu, koristi šire značenje. S. Jambrek, Reformacija, 16-17.

${ }^{16}$ Više o luteranima i kalvinima u: S. Jambrek, Reformacija, str. 15-18.

${ }^{17}$ HR-HDA-1450, D-1740, 1767., Assent lista, fol. 2

${ }^{18}$ Grof Anton Ignatz Mercy-Argenteau bio je posjednik dotične linijske pješačke pukovnije od 1741. sve do 1767. godine kada novi posjednik postaje grof Jakob Nugent. Od 1769. pukovnija je nosila redni broj 56. Alphons freiherrn von Wrede, Geschichte der K. und K. Wehrmacht I (Beč: L.W Seidel \& Sohn, 1898), 507-508.

${ }^{19}$ Furir je bio dio administrativnoga osoblja, prvenstveno u ulozi zamjenika i pomoćnika računovođe i gruntovničara. Buczynski, Gradovi Vojne krajine, 332.
} 
brojala ukupno 2837 aktivnih pripadnika. ${ }^{20}$ Obitavao je u Kupinovu i obavljao administrativne poslove za satniju koja je pokrivala sela Kupinovo, Ašnju, Obrež, Vitojevce, Ogar i Donji Tovarnik. ${ }^{21} \mathrm{U}$ navedenim je selima živjelo ukupno 1660 pravoslavnih i 7 katoličkih muških stanovnika, od kojih je u aktivnoj službi satnije bilo njih $231 .{ }^{22}$

Zajedno s onom Riegelovom za 1767. godinu ukupno je sačuvano devet pristupnih listi, datiranih od 1. siječnja do 1 . studenoga. ${ }^{23}$ Osim kronološki druge po redu, koja se odnosila na nižega časnika i puhača Johanna Georgea Krausa, trinaestogodišnjega katolika iz Banata, ostalih osam listi odnosilo se na furire. Uzme li se u obzir da je broj furira u Pukovniji bio vrlo ograničen (jedan po satniji), pristizanje ovolikoga broja novih tijekom 1767. godine predstavljalo je znatno restrukturiranje cijeloga nižeg administrativnog kadra. Bio je to dio procesa reorganizacije koji je Petrovaradinska pukovnija prolazila u vremenu nakon Sedmogodišnjega rata. Osim Riegela isti je proces rekonstrukcije u redove Pukovnije 21. ožujka doveo još jednoga protestanta. Riječ je o Jonasu Vozariju (ili Woczaryu), također furiru koji je prethodno služio pod Adamom Bathyanijem i četiri godine u redovima kirasira Carla Pálffyja. ${ }^{24}$ Prilikom dolaska naveden je kao oženjen evangelistički (luteran) tridesetijednogodišnjak rođen u Ratkovu u Ugarskoj te je dodijeljen satniji Böhr (Slankamenska) i nastanio se u Slankamenu. ${ }^{25}$ Bio je zadužen za područje koje je osim Slankamena pokrivalo još i selo Krčedin. Ukupno je u navedena dva mjesta živjelo 949 pravoslavnih i 29 katoličkih muških stanovnika, od kojih je u aktivnoj službi satnije bilo njih $128 .{ }^{26}$

Furiri su iz perspektive satnije, kao najniže upravne jedinice unutar Vojne krajine, igrali relativno važnu ulogu u okruženju koje često nije nadilazilo nekoliko sela. Kao praktički jedini predstavnici administracije i produžena ruka pukovnijskoga računovođe, koji se nalazio u stožernome mjestu Mitrovici, morali su biti obrazovani i vladati barem osnovnim matematičkim i pisarskim vještinama. Upravo im je to davalo posebnost u odnosu na okruženje u kojemu su se nalazili. Promatrajući strukturu furira prema religijskoj pripadnosti, nakon provedene

${ }^{20}$ HR-HDA-1450, D-1740, 1767., Monath Tabella, fol. 1.

${ }^{21}$ Već je u veljači satnija dobila novoga zapovjednika Michaela von Frankolukyja, katolika iz Osijeka, i shodno tome promijenila ime u Frankoluky (Kupinovsku) satniju. S obzirom da su se zapovjednici, a stoga i sami nazivi, mijenjali relativno učestalo, satnije su još imenovane i prema svojim stožernim mjestima, a koje je u ovome slučaju bilo Kupinovo. Satnija se prostorno nalazila u istočnome Srijemu uz rijeku Savu. (HR-HDA-1450, D-1740, 1767., Monath Tabella, fol. 2; D-1554., 1767., fol. 24)

${ }^{22}$ HR-HDA-1450, D-1554, 1767., fol. 24.

${ }^{23}$ HR-HDA-1450, D-1740, 1767., Assent lista, fol. 2-9.

${ }^{24}$ Grof Carl Paul Pálffy bio je posjednik navedene kirasirske pukovnije od 1734. do 1773. godine, osnovane 1689. i raspuštene 1775. godine za vrijeme idućega posjednika Georga Heinricha baruna von Rothschütza. Alphons freiherrn von Wrede, Geschichte der K. und K. Wehrmacht III (Beč: L.W Seidel \& Sohn, 1901), 586.-589.

${ }^{25}$ HR-HDA-1450, D-1740, 1767., Assent lista, fol. 5.

${ }^{26}$ HR-HDA-1450, D-1554, 1767., fol. 19. 
rekonstrukcije 1767. godine dobiva se uvid da je u službi pukovnije bilo šesnaest katoličkih i dva protestantska furira, dok nije bio niti jedan pravoslavni. Struktura njihova podrijetla ${ }^{27}$ također daje informativan uvid.

Grafikon $1 .{ }^{28}$ Zemlja podrijetla pukovnijskih furira 1767.

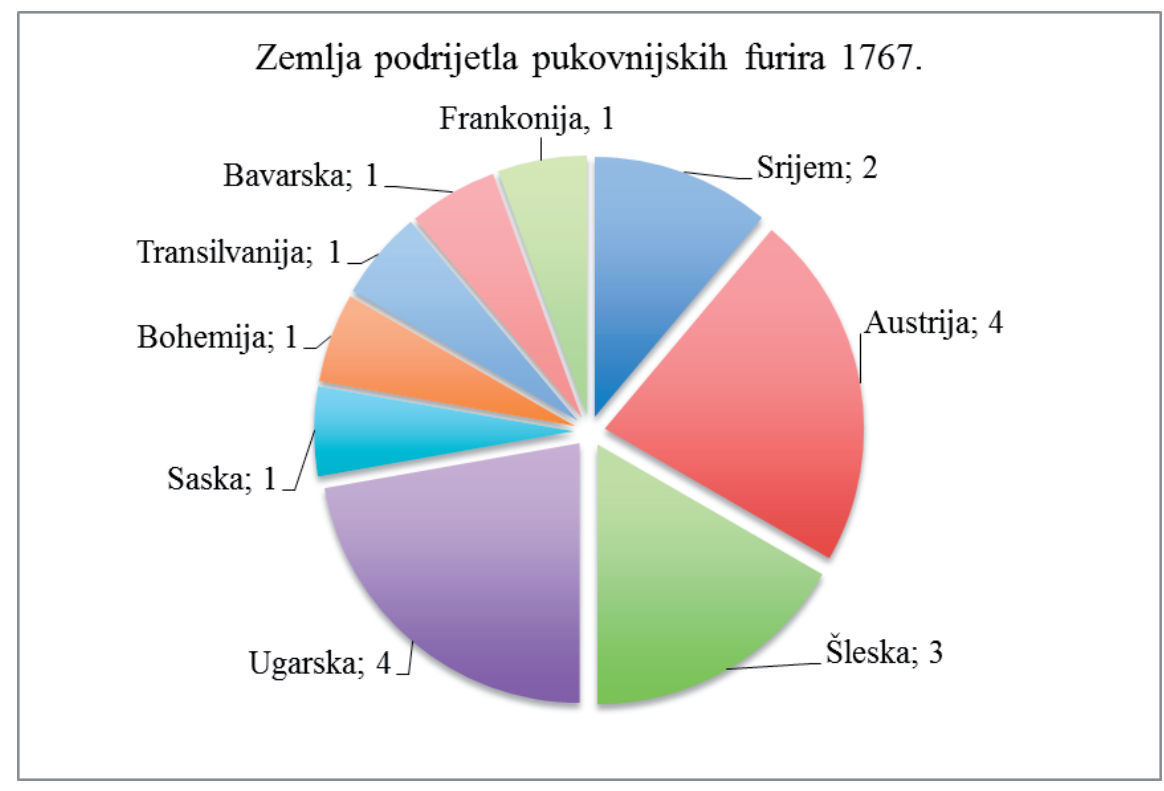

S obzirom da je svega dvoje furira zapravo bilo iz samoga Srijema, dok je velika većina njih dolazila iz raznih dijelova Monarhije pa čak i šire, nije čudno što je upravo kroz ovaj čin i službu ostao prvi zabilježeni ulazak protestantskoga elementa u Petrovaradinsku pukovniju. Posebno je indikativno što su u redovima

\footnotetext{
${ }^{27}$ Prikaz podrijetla pojedinaca prvenstveno se temelji na terminima navođenima u izvorima. U promatranim serijalnim vojnim spisima i popisima Pukovnije gotovo su uvijek za pojedince navođene kategorije aus Land(schaft) i von Orth(schaft) ili pak samo aus $i$ von, a što bi predstavljalo zemlju i mjesto odakle dolaze. U navođenju zemlje uglavnom su se navodile pokrajine, provincije, krunske zemlje itd., a vrlo rijetko veće cjeline poput Njemačkoga Carstva (u izvorima samo Reich ili pak $D(T) e u t s c h e s$ Reich, a odnosilo se na Sveto Rimsko Carstvo koje je postojalo sve do 1806. godine). U slučaju Habsburške Monarhije isključivo su se navodile pojedine sastavnice iako je i u ovome slučaju bilo više varijacija. Tako je termin Austrija (Österreich) obuhvaćao Unutarnju (Innerösterreich), Gornju (Oberösterreich) i Donju (Unterösterreich ili Österreich unter der Enns) Austriju, a koje su ponekad navođene samostalno, kao i pokrajine poput Štajerske i Koruške koje su također vrlo često samostalno stajale kao zemlja podrijetla. U slučaju Ugarske i hrvatskih zemalja u spisima Petrovaradinske pukovnije nešto je ustaljenija terminologija vjerojatno zbog geografske i državne neposrednosti. Premda nije bilo isključivo pravilo, pod terminom Ugarska (Ungarn) uglavnom se smatrao prostor onodobne Ugarske bez Transilvanije i hrvatskih zemalja, a ponekad i bez Bačke i Banata, koji su mogli biti i samostalno upisani kao zemlja podrijetla. Hrvatske su zemlje navođene relativno dosljedno i to kao Dalmacija, Lika, Hrvatska, Slavonija i Srijem. (nap. a.)

${ }^{28}$ HR-HDA-1450, D-1554, 1767., fol. 6-24.
} 
furira bila čak dvojica protestanata, obojica luterani, a na početku i jedine osobe neke od vjeroispovijesti proizašlih iz tradicije reformacije u službi Pukovnije koja nije imala sličnih krajiških obitelji koje su u tome trenutku obitavale na njezinome prostoru prema popisu iz 1767. godine, dok iz redova prevladavajućega pravoslavnog stanovništva nije dolazio niti jedan pripadnik ovoga čina. Razloge ovomu treba tražiti u potrebnoj razini formalnoga obrazovanja i specifičnosti zaduženja koje su furiri obavljali u sklopu krajiškoga sustava.

Treći i ujedno posljednji protestant koji je u službu Petrovaradinske pukovnije ušao 1767. godine bio je potpukovnik Wilhelmus Ludwig Gustaf grof von Wartensleben. ${ }^{29}$ Premješten je 1 . lipnja iz Đurđevačke krajiške pješačke pukovnije $s$ istim činom te je smješten u stožerno mjesto Mitrovicu. Došao je na mjesto potpukovnika Raskovicha, koji je nakon odlaska dotadašnjega pukovnika Mathesena u Glavno zapovjedništvo u Osijeku s promaknućem u generala bojnika postao novim zapovjednikom Pukovnije. Imao je u tome trenutku 32 godine i bio je samac, a rođen je u Extenu u Hessen-Kasselu. Pod stavkom religije navedena mu je reformirana konfesija (reformirt), a što upućuje da je bio kalvin. ${ }^{30} \mathrm{Za}$ razliku od Riegela i Vozarija, koji su bili dijelom građanske klase i pripadali nižoj pukovnijskoj administraciji, u Wartenslebenovu slučaju radilo se o osobi koja je dolazila iz stare vestfalske aristokratske obitelji i koja je stupila na izrazito utjecajnu poziciju unutar Pukovnije. Svoju je vojnu karijeru započeo vrlo rano u redovima Nizozemske vojske da bi potom 1758. godine prešao u carsku službu s činom bojnika u Slunjskoj krajiškoj pješačkoj pukovniji. Čin potpukovnika dobio je 1762. godine zbog posebnoga isticanja tijekom Sedmogodišnjega rata (1756. - 1763.). ${ }^{31}$ Prve godine mira proveo je kao potpukovnik u Đurđevačkoj krajiškoj pješačkoj pukovniji odakle je došao u Srijem. Time je sa svega 32 godine već imao (osim ratnog) i veće iskustvo visoke službe u vojnoj krajini, posebno jer je do dolaska u Slavonsku već prošao kroz Karlovačku i Varaždinsku vojnu krajinu s visokim činovima.

Prvi korak rekonstrukcije Petrovaradinske pukovnije nakon Sedmogodišnjega rata dovršen je 1768. godine, a prvenstveno je obilježen inkorporacijom vlaste-

\footnotetext{
${ }^{29}$ Wilhelmus Ludwig Gustaf grof von Wartensleben (1734. - 1798.) začetnik je mlađe, austrijske loze obitelji Wartensleben nakon što je 1773. oženio groficu Klaru Teleki i s njom imao šestero djece. S druge su strane stariji ogranci obitelji Wartensleben dali nekoliko izrazito istaknutih časnika i generala pruske vojske. Wilhelmus je u carskoj službi napredovao sve do kraljevskoga i carskoga topničkoga generala. Odlikovan je zapovjedničkim činom Vojnoga reda Marije Terezije 21. travnja 1790. Posljednje godine života proveo je kao zapovjednik Transilvanijskoga generalata. Constant von Wurzbach, Biographisches Lexicon des Kaiserthums Öesterreich - 53 Theil (Beč: K.K. Hof- und Staatsdruckerai, 1886), 112; Jaronim Hirtenfeld, Der Militär-Maria-Theresien-Orden und seine Mitglieder (Beč: K.K. Hof- und Staatsdruckerai, 1857), 282; Julius von Wartensleben, Nachrichten von dem Geschlechte der Grafen von Wartensleben, Zweiten Teil (Berlin: Albert Rauch und Comp, 1858), 47-48, 157; Ernst Heinrich Kneschke (ur.), Neues allgemeines deutsches Adels-Lexicon, Neunter Band (Leipzig: Friedrich Voigt's Buchhandlung, 1870), 485.

${ }^{30}$ HR-HDA-1450, D-1554, 1767., fol. 2.

${ }^{31}$ Hirtenfeld, Der Militär-Maria-Theresien-Orden, 281.
} 
linstva Vojke i povećavanjem aktivnoga stanja. ${ }^{32}$ Međutim, proces je donio i znatne izmjene u pogledu časnika i činovnika, što je dovelo do prvoga prodora protestantskoga elementa $u$ inače isključivo katolički i pravoslavni svijet. U ovome smislu posebno je važna činjenica što je drugu najutjecajniju poziciju preuzeo upravo njemački protestant, izdanak obitelji koja se aktivno borila na suprotnoj strani u prethodna dva sukoba, prvenstveno uzimajući u obzir ratni put, znatne gubitke i izrazito veliko opterećenje koje je Petrovaradinska pukovnija pretrpjela tijekom Sedmogodišnjega rata prije svega nekoliko godina. Wartensleben se kao Raskovichev zamjenik zadržao u Pukovniji dvije godine sve dok u svibnju 1769. godine nije preuzeo zapovjedništvo nad Otočkom krajiškom pukovnijom. ${ }^{33}$ Unatoč njegovu odlasku prisutnost protestantskoga elementa u Pukovniji ostala je nepromijenjena s obzirom da je na upražnjenu potpukovničku poziciju već 26 . svibnja došao jedan drugi protestant. ${ }^{34}$

Wilhelm von Klebeck, ${ }^{35}$ nasljednik potpukovnika Wartenslebena, u Petrovaradinsku je pukovniju s istim činom i dužnosti došao iz Gradiške pukovnije. Kao protestant rođen 1729. godine u Losdonu, Livoniji, ${ }^{36}$ u popisu iz 1772. godine označen je kategorijom stranca koji je imao neposrednoga ratnog iskustva. Pod stavkom religijske pripadnosti stajalo mu je sonst accatholish, čime nije preciznije određeno radi li se o luteranu ili kalvinu. Osim toga iz istoga popisa saznajemo da nije bio oženjen i da je smješten je u Mitrovici. ${ }^{37}$ Klebeck je, slično kao i Wartensleben, vrlo rano započeo vojnu karijeru. U početku je služio kao kadet u kirasirima da bi kasnije dobio poziciju zastavnika u pješaštvu gdje je tijekom Sedmogodišnjega rata napredovao sve do čina bojnika. Potpukovnikom postaje nakon rata i s tim je činom proveo ukupnu službu u Petrovaradinskoj pukovniji da bi 1773. godine preuzeo mjesto zapovjednika i pukovnika Križevačke pukovnije u Varaždinskoj vojnoj krajini. ${ }^{38}$

\footnotetext{
${ }^{32}$ Više o procesu inkorporacije vlastelinstva Vojke i kretanju aktivnoga stanja Petrovaradinske pukovnije 1765. - 1768. godine u: Slavko Gavrilović, "Vlastelinstvo Vojka u Sremu (1745-1766), Godišnjak Filozofskog fakulteta u Novom Sadu / Годишнјак Филовофског факултета у Новом Саду 4 (1959): 2959; Pavao Nujić, "Između očekivanja i stvarnosti - Pogled na Petrovaradinsku pukovniju kroz serijalne vojne popise 1765. - 1768.", Acta Histriae 26 (2018), br. 2: 429-448.

${ }^{33}$ Iako je odmah preuzeo zapovjedništvo nad Otočkom pukovnijom, u čin pukovnika promaknut je tek 1773. godine. Hirtenfeld, Der Militär-Maria-Theresien-Orden, 281.

${ }^{34}$ HR-HDA-1450, D-1739, 1769., fol. 5.

${ }^{35}$ Wilhelm barun von Klebeck (1729. - 1811.) u kraljevskoj i carskoj službi napredovao je sve do čina generala topništva. Dobitnik je Maloga križa za pothvate tijekom Rata za bavarsko nasljeđe (1778. -1779.) i čina zapovjednika Vojnoga reda Marije Terezije za posebno isticanje tijekom juriša na Beograd 30. rujna 1789. godine. Posljednja služba bila mu je pozicija zapovjednika utvrde Maastricht. Hirtenfeld, Der Militär-Maria-Theresien-Orden, 256-258.

${ }^{36}$ Livonija je bilo baltičko vojvodstvo koje se nalazilo na dijelu prostora današnje Latvije i Estonije.

${ }^{37}$ HR-HDA-1450, D-1555, 1772., fol. 1.

${ }^{38}$ Hirtenfeld, Der Militär-Maria-Theresien-Orden, 256.
} 
Iz svega navedenoga sličnost $\mathrm{u}$ karijeri i vojnome putu Klebecka i njegova prethodnika Wartenslebena jest očigledna, a odredila ju je malena razlika u godinama, plemićko podrijetlo, rani početak vojne karijere, pokazana sposobnost na bojnome polju i u službi te uska povezanost s Hrvatskom i Slavonskom vojnom krajinom. Petrovaradinska pukovnija poslužila im je kao mjesto potpukovničke službe na nekoliko godina neposredno prije nego su samostalno preuzeli zapovjedništvo nad nekom drugom krajiškom pukovnijom. Promatrana dva protestanta imaju i velike sličnosti u karijeri s drugim uspješnim katoličkim i pravoslavnim časnicima, posebno onima koji su služili unutar Vojne krajine. Uzmemo li u obzir njihovo brzo vertikalno napredovanje te činjenicu da su i prije Patenta o vjerskoj toleranciji iz 1781. godine već bili dugogodišnji i zasluženi zapovjednici krajiških pukovnija, protestantska konfesionalna pripadnost očigledno im nije stvarala nikakve veće prepreke. Wartensleben je do Patenta već bio i general bojnik te vlasnik-posjednik 28. pješačke linijske pukovnije, dok je Klebeck dobio svoje prvo odlikovanje Vojnoga reda Marije Terezije, najviše vojne počasti Habsburške Monarhije. ${ }^{39}$

\section{Popis Pukovnije 1772. i nova perspektiva}

Prijelaz desetljeća donio je nekoliko promjena u Pukovniji. Povećan je broj sela krajiškoga prostora, ukinute su grenadirske satnije, uvedeni su oštrostrijelci i artiljeristi, uveden je trokolonski sustav itd. ${ }^{40}$ Međutim, na promatranome polju protestantske službe došlo je vjerojatno i do najvećih kvalitativnih pomaka. Ključna stavka u ovome pogledu bilo je uključivanje sela Pazove (danas Stara Pazova) u krajiški pukovnijski prostor, koji je od kasnih 1760.-ih godina bio poprištem naseljavanja Slovaka protestanata. Novu stvarnost ovoga stanja donosi neposredni kompletni popis aktivnoga stanja iz 1772. godine. ${ }^{41}$

Te je godine Petrovaradinska pukovnija brojala ukupno 4106 aktivnih krajišnika podijeljenih $\mathrm{u}$ šesnaest satnija. $\mathrm{U}$ ovome pogledu - u odnosu na prethodni popis - najveće su promjene u povećanju broja aktivnih pripadnika i izostanku dvije grenadirske satnije. Stožer se sastojao od trinaest pripadnika od kojih nam je već

\footnotetext{
${ }^{39}$ Vojni red Marije Terezije osnovala je carica i kraljica Marija Terezija 18. lipnja 1757., odnosno na sam dan velike pobjede nad pruskim kraljem Fridrikom II. u Bitci kod Kolina. Odlikovanje i članstvo u Redu osmišljeni su kao najveća počast za časnike Monarhije zbog posebno istaknutih pothvata na bojnome polju. Prvotno su postojali Viteški (Mali) križ i Veliki križ, a Josip II. uveo je i Zapovjednički križ. Glavni je meštar Reda bio sam car Franjo I., a zatim njegovi nasljednici. Odlikovanja su osim počasti sa sobom nosila i izdašne mirovine za svoje nositelje. Hirtenfeld, Der Militär-Maria-Theresien-Orden, 1-4.

${ }^{40}$ Godine 1771. vojne su vlasti ukinule krajiške grenadire te su umjesto njih uspostavile oštrostrijelce i artiljeriste. Oštrostrijelci su zajedno s topnicima činili odvojene postrojbe pojedine krajiške pukovnije. Više u: Alexander Buczynski, "Vojna krajina u 18. stoljeću. Širenje krajiškog sustava na oslobođena hrvatska područja", Povijest Hrvata, Od kraja 15. stoljeća do kraja Prvog svjetskog rata (Zagreb, Školska knjiga, 2005), 279-280.

${ }^{41}$ HR-HDA-1450, D-1555, 1772., fol. 1-17.
} 
poznat jedan protestant, potpukovnik Klebeck, dok ih je sedam bilo odsutnih, a dva prekobrojna viša časnika. Prema konfesionalnoj pripadnosti pukovnijski stožer sastojao se od devet katolika (69 \%), tri protestanta (23\%) i jednoga pravoslavca $(8 \%){ }^{42}$

Vidimo da je među svega trinaest pripadnika stožera 1772. godine bio jednak broj protestanata kao i u cijeloj Pukovniji prije pet godina. Iako je taj podatak u skladu s navedenim zaključcima o mobilnosti protestanata među časnicima te sukladno tome njihovu porastu, nerazmjer u omjeru s pravoslavnim časnicima u ovome je slučaju potrebno posebno izdvojiti. Nezastupljenost pravoslavnoga elementa u Pukovniji, koja je pretežno pravoslavne konfesije, među furirima nije toliko iznenađujući podatak, ali je svakako neobična prisutnost samo jednoga pojedinca među stožernim časnicima. Također je velika zastupljenost katolika unutar časničkoga kadra očekivana stavka zbog općenite katoličke naravi Monarhije. Jedini pravoslavac bio je pukovnik i zapovjednik Alexander von Raskovich, koji je $\mathrm{u}$ trenutku popisa bio odsutan s neposredne dužnosti zbog bolesti. U njegovo je ime, stoga, zapovjedničke dužnosti obavljao drugi najviše rangirani časnik, potpukovnik Wilhelm von Klebeck. Naime, Klebeck nije bio jedini već spomenuti protestant koji se prilikom promatranoga popisa našao kao član stožera. Jonas Vozarij, bivši furir, u međuvremenu je napredovao na poziciju pukovnijskoga računovođe i time postao jedan od voditelja administrativnoga kadra te neposredno nadređen satnijskim furirima. Uzevši u obzir da je na toj poziciji naslijedio katolika, te da je u prethodnom popisu omjer bio šesnaest katoličkih nasuprot dva protestantska furira, očigledno u ovome slučaju pripadnost katoličanstvu nije donosila veće prednosti, a napredovanje unutar administrativnoga kadra protestantima nije bilo otežano. Osim već poznatih, popis donosi i jedno novo ime. Riječ je o pukovnijskome tamničaru Hermuthu Hessu, 47 godina starome protestantu rodom iz Hessen-Kassela. Sva trojica prebivali su u Mitrovici. ${ }^{43}$ Iz navedenoga proizlazi da protestanti u danome trenutku na najvišim razinama Pukovnije jedino nisu bili zastupljeni unutar liječničkoga kadra gdje su bili isključivo katolici. Njihov je utjecaj stoga bio izrazito prezastupljen, posebno u odnosu na radikalno podzastupljene pravoslavce. Situacija se, doduše, znatno mijenja spuštanjem na niže razine, na satnije, gdje je odnos između zapovjednoga i administrativnoga kadra te okolnoga žiteljstva bio kudikamo izravniji. Tako je sastav Pukovnije bez stožera prema konfesionalnoj pripadnosti prikazan na idućemu grafikonu.

${ }^{42}$ HR-HDA-1450, D-1555, 1772., fol. 1.

${ }^{43}$ Isto. 
Grafikon 2. ${ }^{44}$ Krajišnici Pukovnije prema vjeroispovijesti 1772.

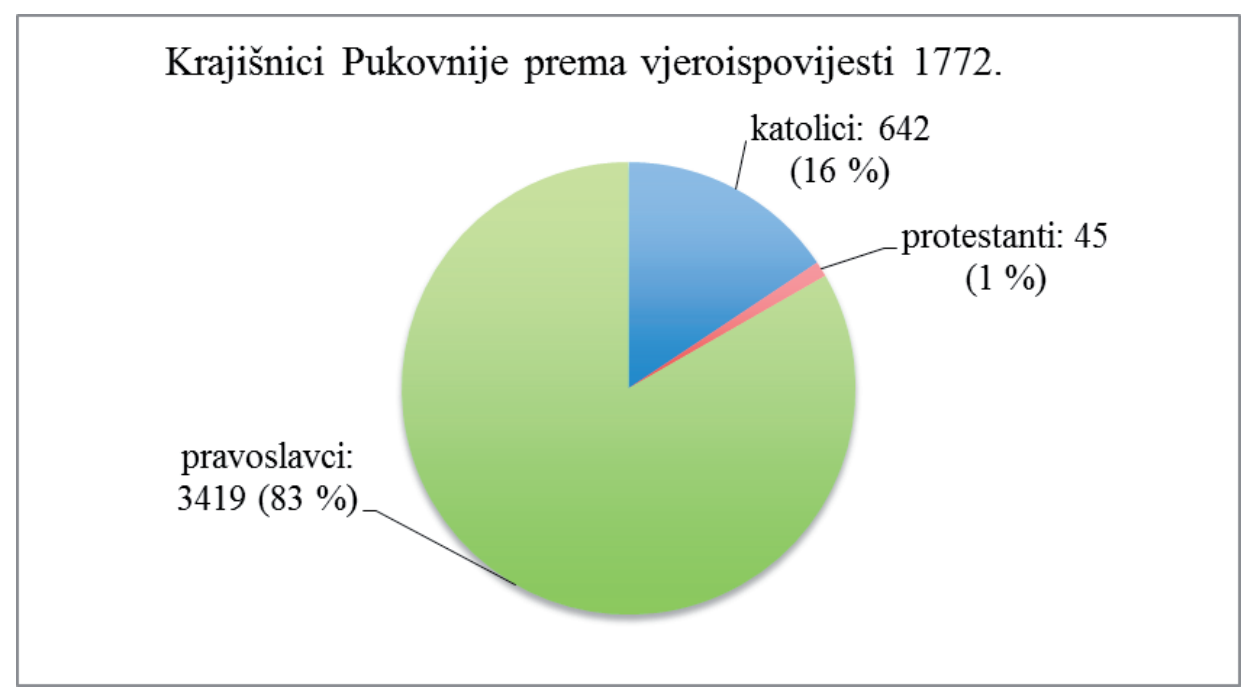

U navedenome su prikazu uključeni svi aktivni krajišnici unutar satnija, zajedno s nižim i višim satnijskim časnicima. Čak 45 zabilježenih protestanata, iako predstavljaju svega nešto više od jedan posto ukupnoga broja, značili su povećanje te kategorije u prethodnih pet godina za više od dvadeset puta. ${ }^{45}$ Uvidom u njihovo zaduženje, odnosno rang i čin, pronalazimo jednoga narednika, dva furira i čak 42 obična pješaka. Iz toga vidimo da su od ukupno 45 protestanata bila svega tri časnika, dok su svi preostali bili obični pješaci. Broj furira ostao je nepromijenjen u odnosu na prethodni promatrani popis iz 1767. godine, čime je njihova relativna zastupljenost unutar administracije na satnijskoj razini povećana u odnosu na katolike s obzirom da je broj satnija smanjen s osamnaest na šesnaest. ${ }^{46}$ Radilo se i o novim pojedincima, Johanu Strömlingu iz Saske i Johannu Heinrichu Heerdegenu iz Bayrutha. Strömling je u Pukovniju došao 1771. godine i imao je u trenutku popisa 29 godina, dok je Heerdegen pristigao svega dva mjeseca prije popisa i imao je 25 godina. Iako više nisu bili furiri, njihovi prethodnici nisu napustili pukovniju. Jonas Vozari znatno je vertikalno napredovao i kao pukovnijski računovođa bio im je nadređen, dok je Johan Gottfried Riegel prešao na poziciju narednika u sklopu iste satnije u kojoj je prethodno obnašao dužnost furira, čime je bio upravo treći zabilježeni satnijski časnik. ${ }^{47}$ Izuzev Wartenslebena, kojega je

\footnotetext{
${ }^{44}$ HR-HDA-1450, D-1555, 1772., fol. 2-17.

45 Tada su u Pukovniji bez stožera bila svega dvojica.

${ }^{46} \mathrm{U}$ novome je sastavu tako bilo četrnaest katoličkih i dva protestantska furira, dok pravoslavci i dalje nisu bili zastupljeni. HR-HDA-1450, D-1555, 1772., fol. 2-17.

47 Isto.
} 
zamijenio Klebeck, svi zabilježeni protestanti koji su pristigli u službu Pukovnije od godine 1767. i dalje su u njoj bili aktivni.

Daleko se veći pomak svakako odvio u pogledu običnih pješaka, posebno s obzirom da do popisa iz 1772. godine uopće nisu bili zabilježeni u Pukovniji. Naime, svih navedenih 42 pješaka protestanata uključeno je "od novih" ${ }^{48} 1$. travnja 1771. u aktivnu službu u sklopu satnije Jovanovich (Banovačka) i bez izuzetka su dolazili iz sela Stare Pazove. ${ }^{49}$ Satnija Jovanovich okupljala je osim Stare Pazove i sela Banovce (stožer), Batajnicu i Vojku te je ukupno brojala 328 aktivnih pripadnika. Sama je Stara Pazova u taj broj davala 76 pojedinaca. Protestantski su krajišnici stoga 1772 . godine činili $12,8 \%$ satnije Jovanovich te $55 \%$ onih koji su dolazili iz Stare Pazove. Ostatak satnije - izuzev četiri katolika - činili su pravoslavci. ${ }^{50}$

Ovakva koncentracija dovela je do nezanemarive zastupljenosti protestantskoga elementa na mikrorazini satnije te posebno bitne iz perspektive Stare Pazove gdje su predstavljali većinu aktivnih u krajiškoj službi. Živjeli su u različitim kućama podjednako raspršenim između brojeva 55 i 182, očigledno dolazeći iz potpuno ili pretežno protestantskih sokaka i ulica. S druge strane, 32 pravoslavna krajišnika dolazila su iz kuća pod brojevima do 55, dok nijedan nije živio u preostalome dijelu sela među protestantima, čime se jasno ocrtava podjela sela na dva konfesionalna dijela. Kod pravoslavaca je općenito, pa tako i u Staroj Pazovi, bila uobičajena pojava da više krajišnika dolazi iz jedne kuće, uglavnom veće zadruge, dok kod protestanata ovom prilikom nije zabilježen niti jedan takav slučaj. ${ }^{51}$ Također je iz navedenih podataka vidljivo kako su pravoslavne kuće prosječno davale gotovo dvostruko veći broj krajišnika nego protestantske. Objašnjenje se može pronaći u dva uzroka koja se međusobno nadopunjuju. Prvi je postojanje već zadovoljene potrebe za aktivnim krajišnicima čime je smanjen intenzitet daljnjega novačenja među vojno sposobnim stanovništvom u vremenu kada se javljaju protestanti, dok bi se drugi mogao tražiti u manjim obiteljima i kućnim zadrugama koje često nisu mogle dati jednoga sposobnog muškarca u vojnu službu. ${ }^{52}$ Proširenje prostora Pukovnije kroz daljnju teritorijalizaciju i poticanje migracija na jednoj strani, te ukidanje grenadirskih satnija na drugoj strani tijekom druge

\footnotetext{
${ }^{48}$ Stavka "od novih" u popisima uglavnom je označavala novouključene pojedince koji nisu imali prethodno vojno iskustvo i koji su neposredno došli na prostor Pukovnije.

${ }^{49}$ U izvorima je selo navođeno samo kao "Pazova" (Pasua, Basua, Pasova itd.), a naziv Stara Pazova (AltPasua) dobilo je nakon što je 1790. godine nastala Nova Pazova (Neu-Pasua).

${ }^{50}$ HR-HDA-1450, D-1555, 1772., fol. 8.

${ }^{51}$ Isto.

52 Prema Kaserovim navodima u Petrovaradinskoj je pukovniji godine 1772. ukupno živjelo 52.491 stanovnik u 7080 obitelji, čime je prosječno jedna obitelj imala 7,4 članova. Uzmemo li u obzir da su u taj broj ulazile i žene, starci i djeca, jedna je prosječna krajiška obitelj najčešće imala svega jednoga odraslog i sposobnog muškarca za vojnu službu, a tek u rjeđim slučajevima po dvojicu. Kaser, Slobodan seljak, 174 .
} 
polovice 1760. godine, znatno su olakšali popunjavanje predviđenoga stanja $\mathrm{Pu}$ kovnije, što je dovelo do navedenoga smanjenja opterećenja i potrebe za novim novačenjima. Pravoslavci iz Stare Pazove mahom su bili nešto ranije unovačeni i do promatranoga popisa prosječno su imali 6,3 godine vojne službe, dok su bila svega petorica novouključenih zajedno s protestantima. ${ }^{53}$

Osim što su živjeli u Staroj Pazovi i bili u isto vrijeme unovačeni, te stoga imali jednu godinu vojne službe, promatrane protestante povezuje još nekoliko stavki. Prvenstveno je u ovome pogledu važna činjenica da se radi isključivo o Slovacima, a zatim da su bili dobrovoljno upisani u vojnu službu, da nisu imali direktnoga ratnog iskustva te da nitko od njih nije imao određenu profesiju niti zanat. Najmlađi među njima imao je 17, najstariji 33, dok je prosjek iznosio 22,2 godine. S obzirom da su imali jednu godinu vojne službe, značilo je da su prosječno unovačeni s 21 godinom. Također je svakome pojedincu zabilježena i tjelesna visina pa tako saznajemo kako je najniži pojedinac imao $158 \mathrm{~cm}$, a najviši $175,8 \mathrm{~cm}$, dok je prosjek svih bio svega $165,5 \mathrm{~cm}$. Iako je riječ o malenome uzorku, navedene podatke o protestantima možemo usporediti s već promatranim pravoslavcima Stare Pazove. Oni su u prosjeku imali 24,8 godina i $170,2 \mathrm{~cm}$ visine te su rodom bili iz Hrvatske (20), Srijema (6), Ugarske (5) i Bačke (1). ${ }^{54}$ Uzmemo li u obzir da su u prosjeku imali više od šest godina vojne službe, dobivamo izračun da su novačeni s prosječno 18 godina, a osim toga, četvrtina ih je imala i direktno ratno iskustvo. Iako su protestanti činili većinu krajišnika u selu Stara Pazova, pravoslavci su bili stariji, ali su u službu ulazili mlađi, imali su znatno veće iskustvo vojne službe i rata te su tjelesnom građom prosječno bili i nešto viši. I jedni i drugi doseljeni su u Staru Pazovu, a kao država podrijetla u popisu je svim protestantima navedena Ugarska. Slučaj je bio bitno raznolikiji po pitanju samoga mjesta rođenja s obzirom da su protestanti dolazili iz ukupno dvadeset različitih sela i gradova, a najzastupljeniji se nalaze na idućemu grafikonu.

\footnotetext{
${ }^{53}$ HR-HDA-1450, D-1555, 1772., fol. 8.

${ }^{54}$ Hrvatska je označavala samo prostor središnje Hrvatske, dok je posebno navođenje Bačke kao zemlje podrijetla nezavisno od Ugarske bila interna nekonzistentnost samih popisivača, a koja se najbolje očitovala u drugačijoj praksi već u slučaju protestanata istoga sela prilikom istoga popisa. Isto.
} 
Grafikon 3. ${ }^{55}$ Mjesto rođenja protestanata Stare Pazove prema popisu 1772.

\section{Mjesto rođenja protestanata Stare Pazove prema popisu 1772 .}

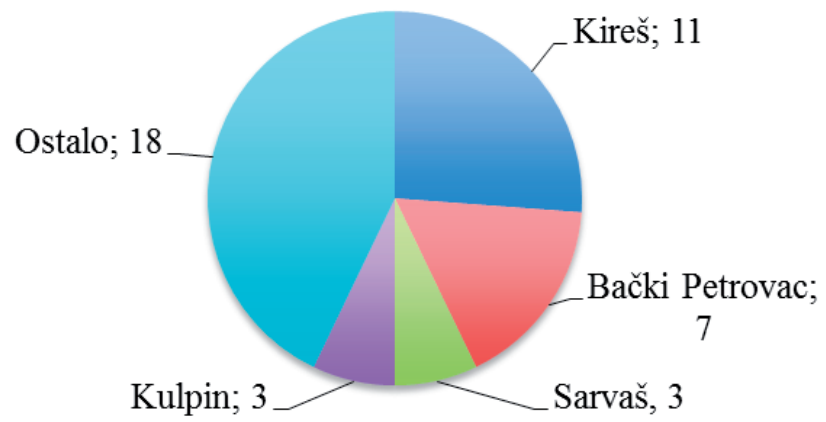

Unatoč znatnoj disperziji mjesta rođenja ipak se ocrtavaju dva središta iz kojih je pridošao veći broj pojedinaca. Najzastupljenije je bilo selo Kireš ${ }^{56}$ iz kojega je došlo nešto više od četvrtine, a slijede ga susjedna sela Bački Petrovac i Kulpin, ${ }^{57}$ koja zajedno broje samo jednoga manje, dok su iz nešto udaljenijega i u ovome pogledu izoliranoga Sarvaša ${ }^{58}$ bila svega tri pojedinca. Preostalih osamnaest pojedinaca dolazilo je iz šesnaest različitih mjesta diljem onovremene Ugarske iz kojih se ne može odrediti prostorna povezanost, kao što je slučaj kod Bačkoga Petrovca i Kulpina. Ono što sva istaknuta naselja povezuje jest snažna migracija evangelističkih Slovaka tijekom 18. stoljeća, koji su uglavnom bili zaslužni za njihova ponovna naseljavanja, obnovu ili osnaživanje. ${ }^{59}$ Ona su poslužila kao privremeno odredište jedne do dviju generacija pojedinih obitelji u migraciji prema jugu. Primjerice, kolonija evangelističkih Slovaka u Bački Petrovac dolazi 1745. godine,

\footnotetext{
${ }^{55}$ HR-HDA-1450, D-1555, 1772., fol. 8.

56 Danas grad u Mađarskoj (mađ. Kiskőrös), dok se u izvorima navodi kao Kis Körös. Srednjovjekovni grad Kireš potpuno je uništen nakon osmanske okupacije, a pustara je ponovno naseljena tijekom 18. stoljeća, između ostalih, evangelističkim Slovacima. Status grada ponovno je dobio tek 1973. godine.

57 Sela u Bačkoj, danas Vojvodina u Republici Srbiji. Bački Petrovac u izvorima je navođen samo kao Petrovac (Petrovacz), a kao zemlja podrijetla svim je pojedincima koji su bili iz ovih bačkih sela navedena Ugarska, što je bilo suprotno već spomenutome slučaju kod pravoslavaca Stare Pazove gdje je Bačka samostalno stajala pod dotičnom kategorijom.

${ }^{58}$ Danas grad u jugoistočnoj Mađarskoj (mađ. Szarvas) u Bekeškoj županiji (mađ. Békés megye) koji je dijelio sličnu sudbinu kao i Kireš.

${ }_{59}$ Naseljavanje Slovaka bilo je rezultat potrebe za repopulacijom prostora koji je oslobođen od osmanske vladavine, a u navedenim su naseljima bili dominantan element duže vrijeme. Kireš danas ima samo slovačku manjinu od nekoliko posto, dok su u Sarvašu, Bačkom Petrovcu i Kulpinu i dalje većinsko stanovništvo.
} 
stoga ne čudi što je svih sedam navedenih krajišnika koji su rodom iz njega, kao i trojica iz susjednoga Kulpina, znatno mlađi od ukupnoga prosjeka, a najstariji je pojedinac imao svega 21 godinu. Međutim, promatrano iz iste perspektive, vjerojatno je i više pojedinaca došlo istim valom migracije koji je prolazio kroz Bački Petrovac, ali su bili stariji od 25 godina i stoga su imali zabilježeno mjesto rođenja odakle su prvotno emigrirali kao djeca s obitelji. Određene crte migracijskih valova očitavaju se i u povezanosti mjesta rođenja i kućnih brojeva stanovanja u Staroj Pazovi. Svi pojedinci kojima je zabilježen Bački Petrovac ili Kulpin kao mjesto rođenja, žive u kućama pod brojevima između 55 i 123, dok su s druge strane, svi pojedinci iz Kireša u kućama pod brojevima od 128 do 182. Slavko Gavrilović u svome radu o naseljavanju Slovaka u Staroj Pazovi navodi da su svi potjecali uglavnom iz Zvolenske i Novogradske županije ${ }^{60}$ te da su prvo došli u Selenče, a zatim 1770. godine u Staru Pazovu. ${ }^{61}$ Međutim, uvidom u njihovo stvarno mjesto rođenja vidimo da je taj proces tekao duže i postupnije s više mjesta u kojima su život provodile po jedna ili dvije generacije prije nastavka migracija.

Popis nam donosi još jednu stavku s kojom se zaključuje presječni uvid u stanje protestanata iz Stare Pazove unutar pukovnijske službe. Naime, radi se o njihovim osobnim imenima i prezimenima, koja ih često u popisu već na prvi pogled distanciraju od pravoslavne i katoličke većine. ${ }^{62}$ Promatrajući prezimena ne možemo zaključiti da su postojale veće obiteljski povezane skupine s obzirom da su 42 krajišnika nosila čak njih 39 različitih. Samo su prezimena Hajnak, Sabian i Schiggak nosila po dva krajišnika, a koji su uglavnom živjeli u susjednim kućama i imali isto mjesto rođenja (Kireš i Schimotovnja) čime je izražena njihova šira obiteljska poveznica. Kao što je uobičajeno, situacija s imenima bila je bitno drugačija. Među navedenim je krajišnicima zabilježeno je petnaest različitih osobnih imena i varijacija, uglavnom relativno prepoznatljivoga slovačkog karaktera. ${ }^{63}$

Dolaskom i naseljavanjem u Staru Pazovu promatrani su Slovaci u konačnici izašli iz civilnoga i ušli u povojačeni prostor Vojne krajine gdje - umjesto uobičajenih poreza i davanja - stupaju u vojnu službu Petrovaradinske pukovnije. Time su postali njezinim prvim protestantskim krajišnicima izvan časničkoga i činovničkoga kadra donoseći sa sobom i odjeke reformacije na najnižu razinu ovoga vojnokrajiškog mikrokozmosa. S obzirom da se u ovome slučaju nije radilo o izoliranim pojedincima ili samostalnim profesionalcima, nego o cijelim obiteljima koje

\footnotetext{
${ }^{60}$ Dvije susjedne županije na sjeveru onodobne Ugarske. Prostor Zvolense županije (mađ. Zólyom megye) danas se nalazi u Slovačkoj, a Novogardska (mađ. Nógrád megye) je i dalje županija u današnjoj Ugarskoj, koja graniči sa Slovačkom.

${ }^{61}$ Gavrilović, "Prilog istoriji”, 63.

${ }^{62}$ HR-HDA-1450, D-1555, 1772., fol. 8.

${ }^{63}$ Tako je dvanaest pojedinaca nosilo ime Janko, Jano ili Janos, zatim slijedi osam zabilježenih imena Palko ili Palo, šet Andrasa, četiri Istoka, tri Gyure, tri Martina itd. Imena Janko, Janos, Palko, Andras i Istok nisu zabilježena niti kod jednoga katolika ili pravoslavca u pukovniji, dok je ime Gyuro i Martin bilo uobičajeno.
} 
su se planski i koncentrirano naselile u dijelovima jednoga sela, možemo govoriti i o nastanku prve prave kolonije protestanata na prostoru ne samo Petrovaradinske pukovnije, nego i Vojne krajine u Hrvatskoj i Slavoniji. Međutim, premda sudeći prema provedenoj analizi, protestanti općenito nisu bili diskriminirani ili ograničavani u aktivnoj vojnoj službi i mogućnostima napredovanja u odnosu na katolike ili pravoslavce, barem u promatranim godinama Petrovaradinske pukovnije, to još uvijek nije bio slučaj i u civilnim segmentima društva.

Prvi protestantski doseljenici u Staroj Pazovi bili su Slovaci i došli su neposredno iz Selenča ${ }^{64}$ odakle su bili prisiljeni otići jer je to bio posjed kaločkoga nadbiskupa. Nadbiskup je 1769. godine odlučio protjerati slovačke protestante sa svojega posjeda, a nastalu je situaciju navodno iskoristio Elijac Bohn u nastojanju da napuči zakupljenu pustaru u Staroj Pazovi. ${ }^{65} \mathrm{Za}$ njihovo je naseljavanje Bohn dobio dopuštenje od carice i kraljice Marije Terzije 26. rujna 1769., a preseljenje je obavljeno 1770. godine nakon žetve i berbe. Dolaskom u Staru Pazovu bilo im je dopušteno ispovijedati svoju vjeru, a smjeli su sagraditi bogomolju bez zvona, koja se nije smjela isticati od drugih običnih krajiških kuća, kao i stan za pastora. Prvi je evangelički pastor bio Samuel Spannagel, koji je služio u Staroj Pazovi od 1770. do 1785. godine. Školu, prema svemu sudeći, nisu imali pravo otvoriti, ${ }^{66}$ dok su izgradnju bogomolje bez zvonika dovršili najizglednije do 1773 . godine ${ }^{67}$

${ }^{64}$ Selenča je selo sa slovačkom većinom u Bačkoj, a danas se nalazi u Vojvodini u Republici Srbiji.

${ }^{65} \mathrm{O}$ ovome događaju postoje oprečna svjedočanstva, a koja također ističe i sam Gavrilović. Naime, druga je verzija da se radilo o Johannesu Bohnu, evangeliku iz Turoca i učitelju u srpskoj gimnaziji u Novome Sadu, koji je dobio dopuštenje za naseljavanje svojih istovjernika na imanju Stara Pazova u Petrovaradinskoj pukovniji. Također se u ovome slučaju navodi da su doseljenici bili samo djelomično iz Selenče. Gavrilović, "Prilog istoriji", 63; Josef Pindor, Die Evangelische Kirche Kroatien-slavoniens in vergangenheit und gegenwart (Osijek, Buchdruckerei Carl Laubner, 1903), 62.

${ }^{66}$ Gavrilović i Pindor navode da su Slovaci protestanti dobili pravo na otvaranje škole, a Pindor čak navodi da je ime prvoga učitelja evangelika bilo Michael Slamaj i da je izgradnja škole dovršena odmah nakon bogomolje. Međutim, u popisima pukovnijske službe ne pronalazi se dotični učitelj Slamaj (što ne znači da nije postojao zbog fragmentiranosti izvora, ali ga se ne može potvrditi iz te perspektive), dok iz nešto kasnijih izvješća ne pronalazimo svjedočanstva o postojanju zasebne protestantske škole, nego samo jedne "njemačke" miješane trivijalne osnovne škole. Također je Dvorsko ratno vijeće 1779. godine ustvrdilo da u Staroj Pazovi nije potrebna posebna škola jer učiteljska služba nije bila povezana s vjerskom pripadnošću i posebno stoga što je vjersku izobrazbu u Staroj Pazovi vodio sam pastor. Obveza da svi stanovnici Stare Pazove bez razlike u vjerskoj pripadnosti svoju djecu šalju u istu školu potvrđena je i 1781. godine. Gavrilović, "Prilog istoriji”, 63, 65; Pindor, Evangelische, 63; Hrvatska, Hrvatski državni arhiv (dalje: HR-HDA), fond Slavonska generalkomanda (dalje: SGK), kutija 16, 1779, fol. 63-40; 1780, fol. 21, 1-14.; kut. 17. 1781, fol. 25-1.

${ }^{67}$ Gavrilović se poziva na Pindora u tvrdnji da je bogomolja izgrađena do 1773 . godine. Također navodi da je pastor Spannagel prekoračio svoje ovlasti i izgradio zvonik na bogomolji te doveo dodatnoga pomoćnog pastora, a što mu je naknadno Petrovaradinska pukovnija zabranila i naredila da zvonik sruši, a pomoćnoga pastora otpusti. Protestanti su kao odgovor u ovome slučaju navodno zatražili pomoć i zaštitu kod Glavnoga zapovjedništva Slavonske vojne krajine u Petrovaradinu (Tih je godina Glavno zapovjedništvo još uvijek bilo u Osijeku, nap. a.), a zatim iznosi da je zvono ipak bilo sagrađeno tek poslije 1785. godine i odlaska pastora Spannagela iz Stare Pazove. Za ove tvrdnje ponudio je navod dokumenta iz fonda Slavonske generalne komande, koji se ne nalazi pod navedenom signaturom (Slavonska generalkomanda, 1766-66-94). Izgledno je da je došlo do pogreške i da se radi o signaturi 1776-66-94, ali se 


\section{Trajnost nove stvarnosti}

Utvrđivanjem prvoga ulaska protestantskoga elementa u službu Pukovnije i analizom cjelovitoga popisa 1772. godine dobiva se uvid iz nekoliko ključnih godina. Premda se time može iščitati kako se i kada reformacija u drugoj polovici 18. stoljeća probila u relativno zatvoreni krajiški sustav, ostaje otvoreno pitanje o njezinoj postojanosti i trajnosti. Za određivanje trajnijega stanja i rezultata tih gibanja potrebno je obuhvatiti šire vremensko razdoblje i odrediti usporednu točku. S obzirom na očuvanost izvora o aktivnome stanju Pukovnije do kraja 18. stoljeća, možemo odrediti dvije vremenske cjeline: razdoblje do i nakon 1792. godine.

Za dva desetljeća između 1772. i 1792. godine izvori su izrazito fragmentirani i izostaje cjelovit popis iz kojega bi se moglo utvrditi precizno stanje, pa tako i točan broj aktivnih protestanata u službi. Prvi popis, koji je po svojoj naravi cjelovit i koji se može kvalitetno usporediti s onim iz 1772. godine, datira upravo iz 1792. godine. ${ }^{68}$ Međutim, bez obzira na izostanak popisa, ali općenito i gotovo bilo kakvih izvora koji bi konkretno svjedočili o aktivnim krajišnicima Pukovnije za više godina navedenoga međurazdoblja, moguće je iščitati konstantu koja je važna za ovaj osvrt, a to je stalna prisutnost i fluktuacija protestanata u najraznovrsnijim službama Pukovnije. Najvažniji i najistaknutiji pojedinac među njima svakako je bio već spomenuti Wilhemus grof von Wartensleben.

Wartensleben se vratio u Petrovaradinsku pukovniju 1774., ovoga puta na mjesto njezina pukovnika i zapovjednika. ${ }^{69}$ Čin pukovnika dobio je prethodne godine za vrijeme službe u Otočkoj pukovniji. ${ }^{70} \mathrm{U}$ međuvremenu je oženio groficu Kláru Teleki de Szék s kojom je dobio prvih dvoje djece upravo tijekom službe u Srijemu, a gdje se zadržao iduće četiri godine. U kolikoj su mjeri središnje vojne vlasti bile zadovoljne njegovim učinkom, svjedoči činjenica da je prilikom izbijanja Rata za bavarsko nasljeđe (1778. - 1779.) dobio i iduće promaknuće u generala bojnika. S obzirom na izrazito visoku razinu moći i širinu ovlasti koje su pukovnici uživali na prostorima svojih pukovnija, činjenica o protestantu pukovniku posebno je indikativna i važna. Specifičnost vojnokrajiškoga prostora, gdje su i vojna i civilna

u dotičnome dokumentu ne govori o godini izgradnje bogomolje u Staroj Pazovi, dodatnome pastoru, zvoniku ili prepisci protestanata Stare Pazove s Petrovaradinskom pukovnijom ili Glavnim zapovjedništvom, nego je riječ o dopisu Dvorskoga ratnog vijeća upućenome na Glavno zapovjedništvo Slavonske vojne krajine u kojemu se bavi pitanjem ograničavanja rasta broja protestanata u Staroj Pazovi. S druge strane, Vaniček tvrdi da je protestantima u Staroj Pazovi sve do 1781. godine uporno bilo uskraćivano pravo izgradnje bogomolje i škole. Međutim, s obzirom da je 1781. godine odlučeno da protestanti Stare Pazove imaju pravo proširiti svoju bogomolju, izgledno je da je ona u nekome obliku ipak postojala i prije te godine. Gavrilović, "Prilog istoriji", 63-64; Pindor, Evangelische, 63; Franz Vaniček, Spezialgeschichte der Militärgrenze II (Beč: K.und K. Hof- und Staatsdruckerei, 1875), 534; HR-HDA, SGK, kut. 13, 1776., fol. 66-94; kut. 17., 1781., fol. 66, 25-1

${ }^{68}$ HR-HDA-1450, D-1556, 1792., fol. 1-17.

${ }^{69}$ Wrede, Geschichte der K. und K. Wehrmacht V, 288.

${ }^{70}$ Hirtenfeld, Der Militär-Maria-Theresien-Orden, 281. 
vlast utjelovljene u svojim zapovjednicima, govori o tome da je Wartensleben kao protestant iz Njemačke imao ovlast u gotovo svim segmentima nad kompletnim stanovništvom koje je bilo unutar vojnoga prostora istočnoga Srijema. U tome je pogledu pomalo paradoksalna situacija s obzirom da su protestantima krajišnicima ograničavana osnovna građanska prava i mogućnost osnivanja svojih vjerskih i obrazovnih ustanova kao i gradnja novih kuća i zasnivanje kućanstava (zbog izostanka tolerancije), ${ }^{71}$ dok je istovremeno na mjestu njezina pukovnika i zapovjednika bio - protestant. ${ }^{72}$ Ovo je tek jedan primjer koji nije bio izoliran, a koji svjedoči o dvostrukim standardima središnjih bečkih vlasti u odnosu lokalnih pravila i propisa te istaknutih pojedinaca u njihovoj službi, što je posebno dolazilo do izražaja na prostorima gdje se susretao vojni i civilni segment.

Svega tri godine nakon Wartenslebenova odlaska iz Pukovnije dolazi jedna druga osoba koju bi ovom prilikom trebalo posebno istaknuti. Naime, radi se o dvadesetogodišnjemu evangelističkom učitelju trivijalne škole Josephu Morvayu, rodom iz Banovaca u Gornjoj Ugarskoj. Iako je po službi bio među najnižim slojevima pukovnije, gotovo sušta suprotnost Wartenslebenu, Morvay je bio od izuzetne važnosti za protestantsku zajednicu Petrovaradinske pukovnije, posebno jer se na istoj službi spominje još i 1797 . godine. ${ }^{73}$ Njegov dolazak označio je svojevrsnu prekretnicu jer je s Patentom o vjerskoj toleranciji, koji je donio car i kralj Josip II. godine 1781., dopušteno, između ostaloga, i protestantima otvaranje svojih vjerskih i obrazovnih institucija u Vojnoj krajini u mjestima gdje ih je bilo više od stotinu. ${ }^{74}$ Također je svim protestantima bez oklijevanja dopušteno i stjecanje građanskih prava. ${ }^{75}$ Međutim, i dalje ostaje otvoreno pitanje je li zaista postojala evangelistička škola u Staroj Pazovi ili je učitelj Morvay djelovao u već postojećoj miješanoj školi. ${ }^{76}$ Prisutnost bogomolje i učitelja, ako ne i cijele škole, djelovali su stimulirajuće u pogledu opstanka i razvoja protestantske kolonije u Pukovniji iako su ih prema pravilima morali sami uzdržavati. ${ }^{77}$

\footnotetext{
${ }^{71}$ Vaniček navodi kako je protestantima u Petrovaradinskoj pukovniji sedamdesetih godina uporno bilo uskraćivano pravo na bogomolju i školu, što upućuje na to da su oni bili proaktivni na planu pokušavanja zadobivanja svojih vjerskih i obrazovnih institucija. Franz Vaniček, Spezialgeschichte der Militärgrenze II (Beč: K.und K. Hof- und Staatsdruckerei, 1875), 534.

${ }^{72}$ Posebno je paradoksalna činjenica da je kraljica i carica Marija Terezija bila zabrinuta za rast protestanata u Staroj Pazovi te je angažirala Dvorsko ratno vijeće, Glavno zapovjedništvo u Osijeku i samu Petrovaradinsku pukovniju da njihov rast suzbiju upravo u vremenu dok je Petrovaradinskom pukovnijom zapovijedao protestant Wartensleben. Od njega kao neposrednoga zapovjednika Pukovnije očekivano je da provodi zabranu izgradnje, kupnje ili preuzimanja novih kuća od protestanata i da se time broj njihovih kućanstava ograniči. HR-HDA, SGK, kut. 13, 1776., fol. 66-94.

${ }^{73}$ HR-HDA-1450, D-1745, 1797., Abgabs lista Joseph Morvay.

${ }^{74}$ Vaniček, Specialgeschichte, 534.

${ }^{75}$ Buczynski, Gradovi Vojne krajine, 128.

${ }^{76}$ Gavrilović navodi opis Stare Pazove iz 1787. u kojemu se spominje samo jedna "njemačka trivijalna škola od tvrdog materijala". Gavrilović, "Prilog istoriji", 65.

77 Mathias Stopfer, Statistik der Militär-Gränze (Graz: Druck und Papier von J.A. Reinreich, 1840), 233.
} 
Pojavljivanje pojedinih protestanata u izvorima u aktivnoj službi Pukovnije intenzivira se tek 1787. godine, odnosno uoči nadolazećega rata s Osmanskim Carstvom 1788. godine. Tijekom iduće tri godine dvadeset protestanata zabilježeno je u premještajnim i pristupnim listama, a njihova služba i mjesto podrijetla prikazani su na iduća dva grafikona.

Grafikon 4. ${ }^{78}$ Služba protestanata u Pukovniji 1787. - 1790.

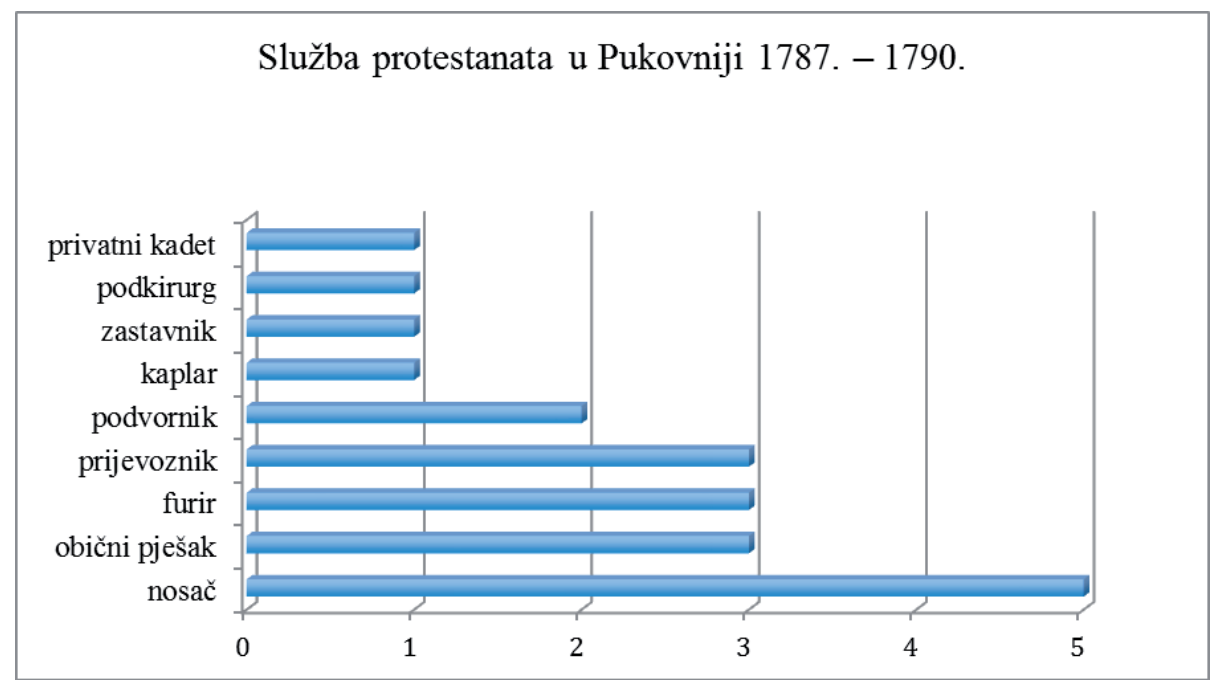

Grafikon 5. ${ }^{79}$ Mjesto ili zemlja podrijetla protestanata 1787. - 1790.

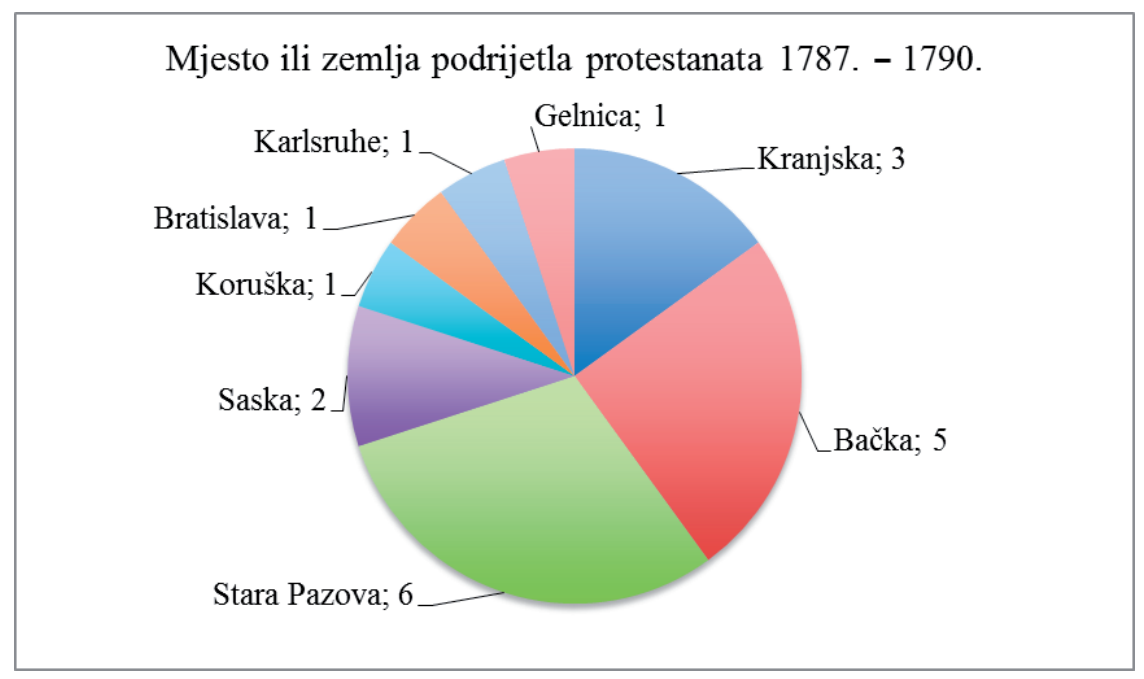

\footnotetext{
78 HR-HDA-1450, D-1740, D-1741, D-1742.

79 Isto.
} 
Iz prikaza je vidljivo da su promatrani protestanti pokazivali znatnu diferencijaciju u činovima i zaduženjima, što i nije iznenađujuće s obzirom na vrstu promatranih izvora ${ }^{80}$ Pet vozača i tri prijevoznika svjedoče o povećanim logističkim pripremama uoči nadolazeće kampanje, a tri furira o nastavku povećanoga utjecaja na području administracije. U pogledu mjesta i zemlje podrijetla došlo je do jedne važne kvalitativne promjene, a koja se, naravno, odnosi na šest pojedinaca koji su rođeni u Staroj Pazovi. Time se ocrtava stupanje druge generacije protestanata u službu, a koji su - za razliku od svojih roditelja - rođeni i odrasli u okvirima te iste Pukovnije i u sklopu krajiškoga sustava i društva. To je jedan od najboljih pokazatelja trajnosti i postojanosti protestantskoga elementa unutar službe Petrovaradinske pukovnije, a koji dodatno potvrđuje i popis iz 1792. godine.

Petrovaradinska je pukovnija 1792. ukupno imala dvanaest satnija i stožer te je brojala 2817 aktivnih krajišnika i 28 pripadnika stožera. Prema popisu protestanata je u sklopu satnija bilo četrdeset, dok je samo jedan bio članom stožera ${ }^{81} \mathrm{U}$ apsolutnim brojevima to bi predstavljalo smanjenje broja aktivnih protestanata s 48, koliko ih je bilo 1772 . godine, na 41 , ali je relativna zastupljenost unutar ukupnoga sastava povećana s $1,2 \%$ na $1,5 \%$ zbog općenite redukcije pripadnika Pukovnije. S druge strane, unutar stožera došlo je do znatnoga pada u pogledu zastupljenosti protestanata. Međutim, jedini protestant u stožeru bio je na poziciji pukovnijskoga računovođe, čime se nastavila iskazivati povezanost pristiglih protestanata i administracije Pukovnije. Riječ je bila o Johannu Gottfriedu Rottigu iz Leipziga, koji je u Pukovniju došao 1786. godine kao furir i unutar nekoliko godina vertikalno napredovao. ${ }^{82}$ Sastav svih aktivnih protestanata prema službi 1792. godine prikazan je na idućemu grafikonu.

\footnotetext{
${ }^{80}$ U pojedinačnim izvorima - kao što su premještajne i izvorne liste - vrlo rijetko nalaze se obični pješaci i dočasnici, a kojih je daleko najviše u sklopu Pukovnije s obzirom da su bili nisko pokretni i novačili su se u ciklusima.

${ }^{81}$ HR-HDA-1450, D-1556, 1792, fol. 1-13.

${ }^{82}$ HR-HDA-1450, D-1556, 1792, fol. 1.
} 
Grafikon 6. ${ }^{83}$ Služba protestanata u Pukovniji 1792.

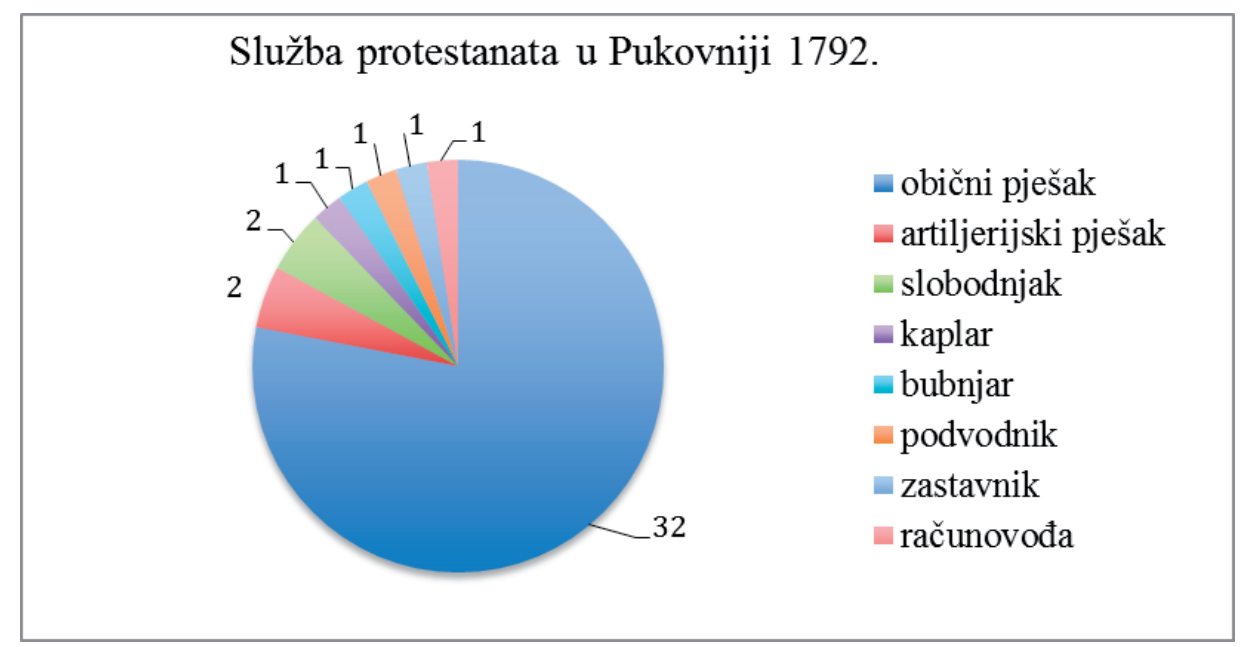

Tijekom dva desetljeća između popisa presječni sastav protestanata prema činovima i službama znatno se ujednačio i više se nije bitno razlikovao od katolika ili pravoslavaca. Kontinuitet se ocrtavao u njihovoj koncentriranosti s obzirom da ih je 38 dolazilo iz Stare Pazove, a koja je u tome trenutku bila u sklopu satnije Brancovich (Golubinačka). Međutim, gotovo sve druge zajedničke karakteristike promatrane skupine bile su manje ili više izmijenjene u odnosu na 1772. godinu pa su tako, primjerice, četiri kuće davale po dva aktivna krajišnika u službu, a za što nije bilo zabilježenoga slučaja u prethodnome popisu. Osim toga, prosječna im je starosna dob porasla na 25,2 godina, dok je vrijeme provedeno u službi bilo 4,8 godina. Postojanje čak deset novaka, koji su u službu ušli iste godine kada je načinjen i popis, te pet veterana, koji su imali više od deset godina iskustva aktivne službe u Petrovaradinskoj pukovniji, svjedoči o njihovoj stabilnoj prisutnosti i izmjeni generacija. ${ }^{84}$ Umjesto trideset različitih mjesta rođenja, ovoga puta brojimo ih svega sedam, a kako su bili zastupljeni, prikazano je na idućemu grafikonu.

${ }^{83}$ HR-HDA-1450, D-1556, 1792, fol. 2-13.

${ }^{84}$ HR-HDA-1450, D-1556, 1792, fol. 5. 
Grafikon 7. ${ }^{85}$ Mjesto rođenja protestanata Stare Pazove 1792.

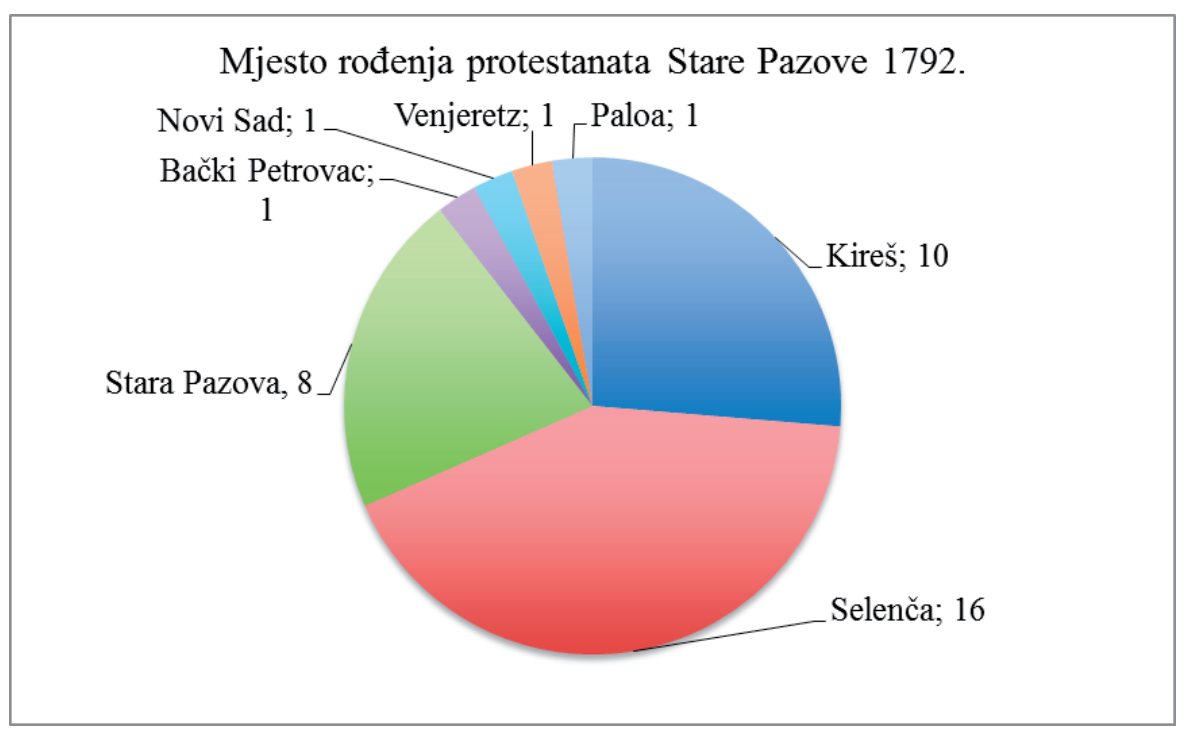

Dok je Kireš ostao gotovo nepromijenjen u pogledu mjesta rođenja promatranih protestanata (Godine 1772. bilo ih je jedanaest.), najveće promjene odnose se na izuzetno veliku zastupljenost Selenče i Stare Pazove. Čak šesnaest aktivnih krajišnika rođenih u Selenči zamijenilo je izrazitu fragmentiranost od prije dvadeset godina, čime se točnije ocrtavaju migracijske etape slovačkih obitelji koje su u konačnici završile u Petrovaradinskoj pukovniji. I dok su svi pojedinci koji za mjesto rođenja imaju zabilježen Kireš bili stariji od 25 godina, što upućuje da su vjerojatno došli kao djeca s obitelji još prije prvoga popisa iz 1772. godine, odnosno u prvome valu doseljavanja protestanata, u slučaju Selenče zabilježena starosna dob oscilira između 18. i 33. godine. S obzirom da je najmlađi pripadnik rođen još 1774. godine u Selenči, znači da je njegova obitelj najranije te godine mogla migrirati na prostor Pukovnije, čime se ocrtava veći raspon godina tijekom kojih su se slovački protestanti doseljavali. ${ }^{86}$ Osim doseljavanja za postojanost protestantske kolonije na prostoru Pukovnije najvažniji je podatak o već znatnoj zastupljenosti pojedinaca rođenih upravo na njezinome prostoru. Osam krajišnika rođenih u Staroj Pazovi bili su u dobi od 17 do 22 godine, od kojih su čak šestorica bili novaci, dok je jedan bio običan pješak, a jedan podvornik. Najstariji od njih, Pallo Thot, bio je stoga jedan od prvih protestanta rođenih

\footnotetext{
${ }^{85}$ Isto.

${ }^{86}$ Marija Terezija je 1776. godine naredila da se povećanje broja luterana (Augspurgische Confession), odnosno svih protestantskih obitelji (Accatolishen Familien) u Staroj Pazovi ograniči kroz zabranu izgradnje, preuzimanja ili pak kupovine novih kuća u svrhu osnivanja dodatnih kućanstava, osim u slučaju posebno važnoga uzroka uz dozvolu i dopuštenje Dvorskoga ratnog vijeća. HR-HDA, SGK, kut. 13, 1776-66-94.
} 
na prostoru Pukovnije koji je kasnije kao mladić ušao u njezinu aktivnu službu. Međutim, prvi zabilježeni takav slučaj druge generacije protestantskih krajišnika bio je Janno Bisovsky. Janno je u službu stupio 1. veljače 1788. s 19 godina, što ukazuje da se njegova obitelj u Staru Pazovu doselila najkasnije 1769. godine. ${ }^{87}$ Višedesetljetna stabilna prisutnost i nove mlade generacije protestanata koje su stasale unutar okvira Petrovaradinske pukovnije i postale njezinim aktivnim članovima vjerojatno su najkonkretniji odjeci reformacije vojnokrajiškoga sustava na prostoru Hrvatske i Slavonije tijekom 18. stoljeća.

\section{Zaključak}

Cjeloviti popisi Petrovaradinske pukovnije iz 1767., 1772. i 1792. godine te drugi serijalni i deskriptivni izvori omogućili su pronalaženje i praćenje protestanata koji su bili dijelom njezine aktivne službe. Premda i za ranije godine postoje izvori o pukovniji, njihov sadržaj ipak ne donosi šire podatke o pojedincima, čime izostaje mogućnost određivanja vjerske i religijske pripadnosti. Međutim, cjeloviti popis iz 1767. godine jasno upućuje na početno činjenično sanje, a to je manja prisutnost protestanata među činovničkim kadrom i njegov potpuni izostanak među lokalnim stanovništvom i običnim krajišnicima.

Promatrajući već prve protestante zabilježene u izvorima, koji su ušli u službu Pukovnije, mogla se odrediti njihova povezanost s administracijom, a što je kasnije i potvrđeno kroz iduća razdoblja. S obzirom na potrebnu razinu pismenosti i formalnoga obrazovanja za obavljanje tih poslova na jednoj strani, te uglavnom njegovoga gotovo potpunoga izostanka kod lokalnoga krajiškog stanovništva na drugoj, jasna je potreba vojnih vlasti za "uvoženjem" osposobljenoga kadra iz drugih krajeva. Prilikom takvoga priljeva činovnika, mahom sa srednjoeuropskoga prostora, nije iznenađujuća pojava i pojedinih protestanata. Međutim, činjenica da su i 1772. i 1792. godine glavni pukovnijski računovođe bili upravo protestanti nadilazi samu njihovu prisutnost u službi te govori i u prilog tome da nisu imali većih poteškoća u napredovanju s obzirom na religijsku pripadnost te da su ostvarili trajni utjecaj na tome području unutar Pukovnije. Slična je situacija bila i s najvišim zapovjednim činovima u desetljeću nakon 1767. godine kada je (gotovo bez prekida) iz redova protestanata dolazio glavni pukovnik i zapovjednik ili pak njegov zamjenik i potpukovnik. Takva akumulacija protestanata na najutjecajnijim položajima Pukovnije kroz duže vrijeme znatno je i povoljno utjecala na formiranje i stabiliziranje protestanata u njezinoj službi.

Premda često zanemareni i previđeni u konfesionalnim statistikama i popisima te analizama Slavonske vojne krajine i Srijema 18. stoljeća, protestanti su bili malen (1-2 \%), ali trajan i stabilan čimbenik Petrovaradinske pukovnije od kasnih

${ }^{87}$ HR-HDA-1450, D-1740, 1789., Transferirungs lista 31. siječnja. 
1760-ih godina. Upravo je kolonija koja se nastanila u Staroj Pazovi te sagradila bogomolju i imala svojega učitelja i pastora bila razlikovni faktor po pitanju prisutnosti reformacije u odnosu na ostale pukovnije Hrvatske i Slavonske vojne krajine promatranih desetljeća. Iako su prvi zabilježeni protestanti u službi Pukovnije bili u sklopu časničkoga kadra, takva pojava nije bila karakteristična za ovu pukovniju. Jasno je to već iz Wartenslebenova i Klebeckova slučaja, koji su u svojoj službi prošli kroz nekoliko pukovnija Hrvatske i Slavonske vojne krajine. Međutim, dok su časnici - napredujući u svojoj karijeri - često mijenjali mjesta službe, pridošli protestanti u Staroj Pazovi došli su sa svojim obiteljima i tamo se trajno nastanili. Kroz dva desetljeća njihov broj u aktivnoj službi ostao je stabilan. U prvome popisu 1772. godine bitnije su odudarali od pravoslavne i katoličke većine, prvenstveno iz razloga što su bili novopridošlice i neposredno unovačeni. Znatnije razlike - poput niže životne dobi, kratke aktivne službe, nepostojanja iskustva direktnoga sukoba, najnižih činova i zaduženja te izostanka većih kućanstava koja su davala više krajišnika - nestale su do 1792 . godine kada iz perspektive aktivne službe u tim parametrima više nisu bili bitno drugačiji od drugih vjerskih skupina krajišnika Petrovaradinske pukovnije. 


\section{Arhivi}

Hrvatska - Hrvatski državni arhiv, Zagreb - fond 1450 - Zbirka mikrofilmova gradiva iz inozemnih arhiva koje se odnose na Hrvatsku (HR-HDA-1450), Mikrofilmovi iz Austrije, Grenz Infanterie Regiment 9, svici D-1554, D-1555, D-1556, D-1740, D-1741, D-1742, D-1745.

Hrvatska - Hrvatski državni arhiv, Zagreb - fond Slavonske generalne komande (HR-HDA, SGK), kutije 13, 16 i 17.

Austrija - Österreichisches Staatarchiv, Kriegsarchiv - Personalunterlagen, Musterlisten und Standestabelle der k.u.k. Armee, Peterwardeiner Grenzinfanterieregiment Nr. 9. (AT-OeStA/KA Pers MLST I GIR 9).

\section{Popis objavljenih izvora i literature}

Božić Bogović, Dubravka. Struktura stanovništva Srijema prema vjeroispovijesti u drugoj polovici 18. i početkom 19. stoljeća na osnovi podataka kanonskih vizitacija. Zbornik Odsjeka za povijesne znanosti Zavoda za povijesne i društvene znanosti Hrvatske akademije znanosti i umjetnosti 27 (2009): 229-291.

Buczynski, Alexander. Gradovi Vojne krajine I. Zagreb: Hrvatski institut za povijest, 1997.

Buczynski, Alexander. "Vojna krajina u 18. stoljeću. Širenje krajiškog sustava na oslobođena hrvatska područja". Povijest Hrvata, Od kraja 15. stoljeća do kraja Prvog svjetskog rata, uredili Mirko Valentić i Lovorka Čoralić, 274-287. Zagreb: Školska knjiga, 2005.

Ćelap, Lazar. "Kolonizacija Nemaca u današnjoj Vojvodini 1790-1792". Zbornik matice srpske za društvene nauke / Sборник матище српске sа друштвене науке 32/33 (1962): 115-124.

Ćosić-Bukvin, Ivica. "Doseljavanje Nijemaca u Srijem tijekom 18. stoljeća". Godišnjak njemačke narodne zajednice (2004): 241-246.

Ćosić, Vesna, Fatović Ferenčić, Stela, Miškić, Blaženka. “O primaljama u Brodu na Savi u XIX. stoljeću”. Acta Medica Histria Adriatica 13 (2015), br. 2: 303-316.

Gavrilović, Slavko / Гавриловић, Славко. Jevreji и Sremu u XVIII i prvoj polovini XIX veka / Јевреји у Срему у XVIII и првој половини XIX века. Beograd: Odeljenje istorijskih nauka - SANU, 1989.

Gavrilović, Slavko / Гавриловић, Славко. "Prilog istoriji Slovaka u Staroj Pazovi 1770-1848. / Прилог историји Словака у Старој Пазови 1770-1848”. Godišnjak Filozofskog fakulteta u Novom Sadи / Годишнјак Филовофског факултета у Новом Саду 16 (1973), br. 1: 63-68. 
Gavrilović, Slavko. "Vlastelinstvo Vojka u Sremu (1745-1766)". Godišnjak Filozofskog fakulteta u Novom Sadu / Годишнјак Филовофског факултета у Новом Саду 4 (1959): 29-59.

Habek, Dubravko. "Primaljstvo i prve primalje u Bjelovaru 1756.-1856". Arhiv za higijenu rada i toksikologiju 59 (2008), br. 3: 223-232.

Hirtenfeld, Jaromir. Der Militär-Maria-Theresien-Orden und seine Mitglieder. Beč: K.K. Hof- und Staatsdruckerai, 1857.

Holjevac, Željko, Moačanin, Nenad. Hrvatsko-slavonska vojna krajina i Hrvati pod vlašću Osmanskog Carstva u ranome novom vijeku. Zagreb: Leykam international, 2007.

Jambrek, Stanko. Reformacija u hrvatskim zemljama u europskom kontekstu. Zagreb: Srednja Europa, 2013.

Kaser, Karl. Slobodan seljak i vojnik I/II. Zagreb: Naprijed, 1997.

Knesche, Ernst Heinrich, ur. Neues allgemeines deutsches Adels-Lexicon, Neunter Band. Leipzig: Friedrich Voigt's Buchhandlung, 1870.

Lazanin, Sanja. "Etničke i konfesionalne skupine u istočnoj Slavoniji i zapadnom Srijemu u 18. i početkom 19. stoljeća". Rasprave in Gradivo 56/57 (2008): 191211.

Lazanin, Sanja. "Naseljavanje njemačkih protestantskih obitelji u Slavonsku vojnu krajinu krajem 18. i početkom 19. stoljeća". Migracijske i etničke teme 34 (2018): 165-198.

Matanović, Damir. Grad na granici - Slobodni vojni komunitet Brod na Savi od sredine 18. do sredine 19. stoljeća. Slavonski Brod: Hrvatski institut za povijest Podružnica za povijest Slavonije, Srijema i Baranje, 2008.

Matanović, Damir. Između reformi i tradicije - Brodska pukovnija od sredine 18. do sredine 19. stoljeća. Slavonski Brod: Posavska Hrvatska, 2013.

Nujić, Pavao. Između očekivanja i stvarnosti - Pogled na Petrovaradinsku pukovniju kroz serijalne vojne popise 1765. - 1768. Acta Histriae 26 (2018), br. 2: 429-448.

Pindor, Josef. Die Evangelische Kirche Kroatien-slavoniens in vergangenheit und gegenwart. Osijek: Buchdruckerei Carl Laubner, 1903.

Skenderović, Robert. "Zdravstvene reforme Marije Terezije u Slavonskom provincijalu i Generale Normativum Sanitatis iz 1770". Scrinia slavonica 5 (2005): 115-143.

Stopfer, Mathias. Statistik der Militär-Gränze. Graz: Druck und Papier von J.A. Reinreich, 1840.

Vaniček, Franz. Spezialgeschichte der Militärgrenze II. Beč: K.und K. Hof- und Staatsdruckerei, 1875. 
Wartensleben, Julius von. Nachrichten von dem Geschlechte der Grafen von Wartensleben, Zweiten Teil. Berlin: Albert Rauch und Comp, 1858.

Wrede, Alphons freiherrn von. Geschichte der K. und K. Wehrmacht V. Beč: L.W Seidel \& Sohn, 1903.

Wrede, Alphons freiherrn von. Geschichte der K. und K. Wehrmacht I. Beč: L.W Seidel \& Sohn, 1898.

Wrede, Alphons freiherrn von. Geschichte der K. und K. Wehrmacht III. Beč: L.W Seidel \& Sohn, 1901.

Wurzbach, Constant von. Biographisches Lexicon des Kaiserthums Öesterreich, 53 Theil. Beč: K.K. Hof- und Staatsdruckerai, 1886. 


\section{Pavao Nujic*}

\section{Protestants in the service of the Petrovaradin regiment in the second half of the $18^{\text {th }}$ century}

\section{Summary}

The area of the Croatian and Slavonian Military Border the $18^{\text {th }}$ century was inhabited by a Catholic and Orthodox population from which Grenzers were recruited, while other religious groups were severely limited in that regard. Protestants were present mostly only within the officer staff of certain regiments and they came from other parts of the Monarchy or even other countries as professionals and only stayed temporarily while their service lasted. In this regard, the Petrovaradin Regiment was not an exception and the arrival of Protestant officers can be traced back to 1767 in the documents and muster rolls of the regiment. A special case was the permanent inhabitation of Protestant families in the area of the Regiment, from which ordinary Grenzers were recruited. Their presence in the service was first noted in a muster roll from 1772 and, from then, can be continuously traced to all levels of the Regiment. The Petrovaradin regiment, therefore, had a steady Protestant minority in its composition throughout the final three decades of the $18^{\text {th }}$ century, which was not common for Military Border. The characteristics of this minority in the article were observed from the perspective of active regiment service, where the changes within the decades had a tendency of gradual equalization with the rest of the troops.

Key words: Military Border, Petrovaradin Regiment, Syrmia, 18th Century Protestants, Grenzers, military service

\footnotetext{
Pavao Nujić, Faculty of Education Osijek, Cara Hadrijana 10, 31000 Osijek, Croatia, E-mail: pnujic@ foozos.hr
} 